\title{
NUTRITIONAL VALUE OF SUGAR BEET PULP AND OLIVE CAKE TREATED BY USING MONISM BIOLOGICAL TREATMENT AND ITS EFFECT ON SHEEP FEEDING.
}

\author{
Hend A. Aziz \\ Animal Nutrition Department, Desert Research Center, Cairo, Egypt.
}

(Received 8/10/2019, accepted 24/11/2019)

\section{SUMMARY}

$\mathrm{T}$ This study included three trials: 1- A laboratory experiment included twelve treatments to study the effect of using biological treatments (yeast, fungi and bacteria) on chemical composition and fiber constituents of sugar beet pulp (SBP) and olive cake (OC) to choose the best biological treatments to be use in in vitro and in vivo experiments. 2- In vitro experiment included five treatments to study the effect of control, untreated and treated SBP and OC on in vitro nutrients disappearance, T(1):Concentrate feed mixture $(\mathrm{CFM})+$ berseem hay $(\mathrm{BH})$ (control). $\mathrm{T}(2)$ : CFM contains (40\% untreated $\mathrm{SBP}+30 \%$ untreated OC) + BH. T(3): CFM contains $(40 \% \mathrm{SBP}+30 \% \mathrm{OC})$ treated with S. cerevisiae+ BH. T (4): CFM contains $(40 \% \mathrm{SBP}+30 \% \mathrm{OC})$ treated with $T$. viride $+\mathrm{BH}$ and $\mathrm{T}(5)$ : CFM contains $(40 \% \mathrm{SBP}+30 \% \mathrm{OC})$ treated with $C$. cellulasea+ BH. 3- In vivo experiment to study the effect of those experiments on sheep digestibility coefficients, rumen fermentations, microbial protein, rumen microbes and some blood parameters. The results revealed a significant improvement $(\mathrm{P} \leq 0.01)$ in $\mathrm{CP}$ content and a significant reduction in $\mathrm{CF}$ and NDF content with biological treatments. Digestibility coefficients and nutritive values were increased $(\mathrm{P} \leq 0.01)$ in treated groups, also, nitrogen balance was enhanced $(\mathrm{P} \leq 0.01)$ than untreated group. Rumen fermentations and microbes showed significant increase $(\mathrm{P} \leq 0.01)$ in treated groups. Serum total protein, albumin and globulin concentrations were more in treated groups, although they reduced urea concentration, GOT and GPT activity.

Keywords: sugar beet pulp, olive cake, digestibility, rumen fermentations, biological treatment and sheep.

\section{INTRODUCTION}

In Egypt there is a developing tendency to increase the sugar production from beet since 1982. The annual amounts of sugar beet pulp are about 385686 tons (Statistics of ministry of agriculture, 2011). Dried sugar beet pulp is a carbohydrate rich by-product. The protein content of sugar beet pulp is considered low compared with the requirements of most ruminants and monogastric animals (Israilides et al., 1994). The crude fiber content of sugar beet pulp is considerably high and the content of fast fermentable carbohydrates and ether extract are much lower than those of high energy grains (Haaksma, 1982). The cellulose structure of sugar beet pulp is mainly amorphous, which make it easily hydrolysable and its pectin content is not covalently linked to a lignified matrix, which make it available source of readily fermentable carbohydrate to enhance the microbial biosynthesis in the rumen (Mansfield et al.,1994).

The impact of feeding dried sugar beet pulp on rumen fermentation was investigated in many studies (Mansfield et al., 1994), however, the results did not show clear trend and they were contradictory. On the other hand, the effect of feeding sugar beet pulp on rumen microbial population and microbial enzymatic activity was poorly studied.

Olive cake is the solid residue generated after extraction of oil from olive crop. The annual amounts of olive cake are about 314450 tons (Statistics of Ministry of Agriculture, 2011). Mainly, $350 \mathrm{~kg}$ of olive cake is produced from one ton of olive. Olive cake as an industrial by-products have low nutritive value, high fiber content and low content of protein and energy, low degradability of cell wall components (Teimouri Yansari et al., 2007), lower digestibility coefficient of nutrients and condensed tannins (Martin Garcia et al., 2003). The poor digestibility and reduce voluntary intake of low quality by- products result 
from extensive lignicafications of cell wall, so the use of biological treatments for these feeds may improve its nutritive value.

The present study aims to improve the nutrient value of sugar beet pulp and olive cake using biological treatments to replace a part of concentrates and evaluate nutrients disappearance, digestibility coefficients, rumen fermentations parameters, microbial protein, rumen microbes and some blood parameters in adult sheep.

\section{MATERIALS AND METHODS}

The field experiments were carried out at Ras Sudr Experimental Research Station, Desert Research Center, located in Southern Sinai Governorate in 2018. The study included laboratory, in vitro and in vivo experiments.

\section{Laboratory experiment:}

A laboratory experiment was designed to study the effect of using biological treatments (fungal, bacterial and yeast) on chemical composition and fiber constituents of sugar beet pulp and olive cake to choose the best biological treatments to be use in in vitro and in vivo experiments. The used biological treatments were obtained from the Microbial Genetic Department, National Research Center, Dokki, Cairo, Egypt. The microorganisms were maintained on agar medium composed of (g/L) yeast extract, 3.0; malt extract, 30; peptone, 5.0; sucrose 20 and agar 20.

The laboratorial experiment was designed as follow:

T (1): Untreated sugar beet pulp (SBP). T (2): SBP inoculated with Saccharomyces cerevisiae. T (3): SBP inoculated with Trichoderma viride. T (4): SBP inoculated with Asarglus orsa. T (5): SBP inoculated with Cellulomonas cellulasea.

T (6): SBP inoculated with Acetobacter xylinum. T (7): Untreated olive cake (OC).

T (8): OC inoculated with Saccharomyces cerevisiae. T (9): OC inoculated with Trichoderma viride. T (10): OC inoculated with Asarglus orsa. T (11): OC inoculated with Cellulomonas cellulasea. T (12): OC inoculated with Acetobacter xylinum.

Amount of $200 \mathrm{~g}$ of each air-dried SBP or OC were moistened for $60 \%$ moisture and inoculated with the biological treatments for 14 days at $30 \pm 2{ }^{\circ} \mathrm{C}$. The used fungi, bacterial and yeast were added by ratio of $1.5 \mathrm{ml}$ media to $100 \mathrm{~g}$ ration plus $10 \%$ molasses solution from the dry matter. Moisture was kept at $60 \%$. At the end of inoculation periods samples were oven dried at $70{ }^{\circ} \mathrm{C}$. Product recovery (PR) was calculated according to Nigam (1994).

\section{In vitro experiment:}

This experiment was designed to study the effect of control, untreated and the best biologically treated sugar beet pulp and olive cake (fungal, bacterial and yeast) according to the results of chemical composition and fiber constituents obtained from laboratory experiment on in vitro nutrients disappearance. Five experiments were carried out as follow:

$\mathrm{T}$ (1): Concentrate feed mixture (CFM) + berseem hay (BH) (control).

$\mathrm{T}$ (2): CFM (contains $40 \%$ untreated SBP $+30 \%$ untreated OC) $+\mathrm{BH}$.

T (3): CFM (contains $40 \% \mathrm{SBP}+30 \%$ OC treated with $S$. cerevisiae) $+\mathrm{BH}$.

$\mathrm{T}$ (4): CFM (contains $40 \% \mathrm{SBP}+30 \%$ OC treated with $T$. viride $)+\mathrm{BH}$.

$\mathrm{T}$ (5): CFM (contains $40 \% \mathrm{SBP}+30 \%$ OC treated with C. cellulasea) $+\mathrm{BH}$.

The concentrate feed mixture for control (T1) consisted of yellow corn (55\%), wheat bran (20\%), soya bean meal $(15 \%)$, molasses $(5 \%)$, limestone $(3 \%)$, salt $(1.5 \%)$ and minerals premix $(0.5 \%)$. while the concentrate feed mixture for untreated (T2) and the other treatments (T3, T4 and T5) consisted of yellow corn $(20 \%)$, SBP (40\%), OC (30\%), molasses (5\%), limestone $(3 \%)$, salt $(1.5 \%)$ and minerals premix $(0.5 \%)$. The ratio of CFM to $\mathrm{BH}$ was $60 \%: 40 \%$ in all treatments.

Ruminal contents were collected, two hours post feeding from six male sheep fed CFM and good quality berseem hay. Collected rumen liquor was kept warm in plastic jug $\left(39^{\circ} \mathrm{C}\right)$, strained through two 
layers of cheese cloth and mixed with urea-buffer under the lab conditions for in vitro studies. The ruminal fluid incubated with the samples of the five treatments, three tubes as replicates for each sample were incubated for 24 hours to estimated dry matter, organic matter and other nutrients disappearance according to the method described by Norris (1976).

\section{In vivo experiment:}

The objective of this experiment was to study the effect of feeding control, untreated and biologically treated SBP and OC (fungal, bacterial and yeast) on digestibility coefficients, rumen fermentation parameters, microbial protein, protozoa count, total numbers of bacteria, and cellulolytic bacteria number and blood parameters for Barki male sheep.

The same five experiments were carried out in the in vitro experiment were used in the in vivo experiment. The experiment was lasted for 50 days. Twenty adult Barki male sheep (four animals for each treatment) were fed on control, untreated and biologically treated SBP and OC for 30 days as a palatability and adaptation period for treatments. Then rams were placed in metabolic cages for 20 days from which the first 15 days were considered as an adaptation and preliminary period, followed by 5 days as collection period. Over the collection period, daily amount of feed consumed, residuals, feces and urine were estimated for each animal. Rams weighted at the start and the end of the trial.

\section{Proximate analysis:}

The proximate analysis for feeds, feces and urine were determined according to the AOAC (1995). Neutral detergent fiber (NDF), acid detergent fiber (ADF) and acid detergent liginin (ADL) were determined according to the procedures of Van Soest (1994).

\section{Determination of second metabolites compounds:}

Approximately $200 \mathrm{mg}$ (DM) of ground samples of dried SBP and OC were extracted in $10 \mathrm{ml}$ of aqueous acetone $(7: 3 \mathrm{v} / \mathrm{v})$ in a water bath maintained at $39-40^{\circ} \mathrm{C}$ for $90 \mathrm{~min}$ (Makkar, 2000). Condensed tannins (CT) were determined according to Porter et al. (1986). Saponins (SAP) were extracted and isolated according to Ahmad et al. (1990). Alkaloids (ALK) were determined according to Arambewela and Ranatunge (1991). Flavonoids (FLA) determination done according to Boham and Kocipai (1994).

\section{Rumen liquor parameters:}

Rumen liquor samples were obtained at 0,2, 4 and 6 hours post feeding. pH was immediately measured using a digital $\mathrm{pH}$ meter. Ammonia nitrogen, total nitrogen and non-protein nitrogen concentrations were determined according to AOAC (1995), while true protein nitrogen was calculated by subtracting the non-protein nitrogen content from total nitrogen content. The total volatile fatty acids (TVFA's) were determined according to Warner (1964). Number of ruminal ciliate protozoa was determined as described by Ogimoto and Imai (1981). Identification of genera and species was according to the description published by Dehority (1993). Dilution series were prepared under $\mathrm{O}_{2}-$ free $\mathrm{CO}_{2}$ by the anaerobic method of Bryant (1972) using the anaerobic dilutes described by Mann (1968) to determine total number of bacteria and cellulolytic bacteria number.

\section{Blood sampling:}

Blood samples were collected via jugular vein from each dietary treatment just before morning feeding and 4 hours post-feeding. Blood samples were left to coagulate at room temperature, then centrifuged at 4000 turn for 15 minute to separate serum and kept it frozen at $-20^{\circ} \mathrm{C}$ till analyses for the total protein according to method of Armstrong and Carr (1964), albumin according to Doumas and Biggs (1971), globulin was calculated by subtracting the albumin from total protein, urea according to Patton and Crouch (1977) and GOT and GPT according to Wikison et al. (1972).

\section{Statistical analysis:}

The data was statistically analyzed according to statistical analysis system of SAS (2004), the data of chemical composition and cell wall constituents analysis (two replicates of samples for each item were used), nutrients disappearance, digestibility coefficients and nitrogen utilization were analyzed by oneway analysis and the model was: $\mathrm{Yij}=\mu+\mathrm{Ti}+$ eij.

The used design for rumen fermentations, rumen microbes and blood parameters was two-way analysis, the model was: $\mathrm{Y}_{\mathrm{ij}}=\mu+\mathrm{T}_{\mathrm{i}}+\mathrm{I}_{\mathrm{j}}+\mathrm{TI}_{\mathrm{ij}}+\mathrm{e}_{\mathrm{ij}}$

Where: $Y_{i j}=$ experimental observation, $\mu=$ general mean, $T_{i}=$ effect of treatment $(i=1: 5), I_{j}=$ effect of time of sampling $(\mathrm{j}=0,2,4$ and 6$), \mathrm{TI}_{\mathrm{ij}}=$ effect of interaction of treatment and time of sampling and $\mathrm{e}_{\mathrm{ij}}=$ experimental error. 
Separation among means was carried out by using Duncan's multiple test (Duncan, 1955).

\section{RESULTS AND DISCUSSION}

\section{Laboratorial experiment:}

\section{Chemical composition and cell wall constituents:}

Data of Table (1) and (2) showed that yeast, fungus and bacterial treatments significantly ( $\mathrm{P} \leq 0.01)$ improved chemical composition and cell wall constituents of SBP and OC comparative with untreated. Treatments with $S$. cerevisiae, $T$. viride and $C$. cellulasea were the greatest $(\mathrm{P} \leq 0.1)$ content of $\mathrm{DM}, \mathrm{OM}$, $\mathrm{EE}$ and $\mathrm{CP}$ for SBP and OC. Whereas they were the lowest $(\mathrm{P} \leq 0.01)$ content of ash, CF, NFE, NFC, $\mathrm{NDF}, \mathrm{ADF}, \mathrm{ADL}$, cellulose and hemicellulose for the two by-products. Treatment with $S$. cerevisiae was the best one for SBP, while treatment with T. viride was the best one for OC. Yeast, fungus and bacterial treatments increased CP content for treated SBP and OC more than untreated SBP and OC, the increase was about $11.65,11.05,10.9,9.85$ and 7.69 for $\mathrm{T} 2, \mathrm{~T} 3, \mathrm{~T} 5, \mathrm{~T} 6$ and $\mathrm{T} 4$; respectively for SBP more than USBP (T1) and about 2.66, 2.30, 2.07, 1.32 and 0.83 for T9, T8, T10, T11 and T12; respectively for OC more than UOC (T7).

Table (1): Effect of treatments on chemical composition, cell wall constituents and product recovery (\%) of sugar beet pulp during laboratorial experiment.

\begin{tabular}{lccccccc}
\hline & \multicolumn{7}{c}{ Treatment } \\
\cline { 2 - 7 } Item & T1 & T2 & T3 & T4 & T5 & T6 & \pm SE \\
\hline Chemical composition\% & & & & & & & \\
DM & $91.10^{\mathrm{f}}$ & $93.00^{\mathrm{a}}$ & $92.90^{\mathrm{b}}$ & $92.20^{\mathrm{e}}$ & $92.82^{\mathrm{c}}$ & $92.66^{\mathrm{d}}$ & 0.025 \\
OM & $90.60^{\mathrm{c}}$ & $92.90^{\mathrm{a}}$ & $92.80^{\mathrm{b}}$ & $92.10^{\mathrm{d}}$ & $92.91^{\mathrm{a}}$ & $92.75^{\mathrm{b}}$ & 0.025 \\
Ash & $9.40^{\mathrm{a}}$ & $7.10^{\mathrm{d}}$ & $7.20^{\mathrm{c}}$ & $7.90^{\mathrm{b}}$ & $7.09^{\mathrm{d}}$ & $7.25^{\mathrm{c}}$ & 0.025 \\
EE & $1.18^{\mathrm{e}}$ & $2.24^{\mathrm{a}}$ & $2.10^{\mathrm{b}}$ & $1.78^{\mathrm{d}}$ & $2.08^{\mathrm{b}}$ & $1.91^{\mathrm{c}}$ & 0.016 \\
CP & $9.20^{\mathrm{f}}$ & $20.85^{\mathrm{a}}$ & $20.25^{\mathrm{b}}$ & $16.89^{\mathrm{e}}$ & $20.10^{\mathrm{c}}$ & $19.05^{\mathrm{d}}$ & 0.021 \\
CF & $24.40^{\mathrm{a}}$ & $19.98^{\mathrm{d}}$ & $19.98^{\mathrm{d}}$ & $21.04^{\mathrm{b}}$ & $20.02^{\mathrm{d}}$ & $20.18^{\mathrm{c}}$ & 0.023 \\
NFE & $55.82^{\mathrm{a}}$ & $50.08^{\mathrm{e}}$ & $50.47^{\mathrm{de}}$ & $52.39^{\mathrm{b}}$ & $50.71^{\mathrm{d}}$ & $51.61^{\mathrm{c}}$ & 0.022 \\
NFC & $19.80^{\mathrm{a}}$ & $15.77^{\mathrm{e}}$ & $16.33^{\mathrm{d}}$ & $17.08^{\mathrm{b}}$ & $16.53^{\mathrm{c}}$ & $16.59^{\mathrm{c}}$ & 0.021 \\
Cell wall constituents\% & & & & & & & \\
NDF & $60.42^{\mathrm{a}}$ & $54.04^{\mathrm{e}}$ & $54.12^{\mathrm{de}}$ & $56.35^{\mathrm{b}}$ & $54.20^{\mathrm{d}}$ & $55.20^{\mathrm{c}}$ & 0.023 \\
ADF & $29.05^{\mathrm{a}}$ & $24.40^{\mathrm{e}}$ & $24.95^{\mathrm{d}}$ & $26.10^{\mathrm{b}}$ & $25.06^{\mathrm{d}}$ & $25.92^{\mathrm{c}}$ & 0.061 \\
ADL & $2.84^{\mathrm{a}}$ & $1.95^{\mathrm{d}}$ & $2.00^{\mathrm{d}}$ & $2.32^{\mathrm{b}}$ & $2.15^{\mathrm{c}}$ & $2.18^{\mathrm{c}}$ & 0.015 \\
Hemicellulose & $31.37^{\mathrm{a}}$ & $29.64^{\mathrm{c}}$ & $29.17^{\mathrm{e}}$ & $30.25^{\mathrm{b}}$ & $29.14^{\mathrm{e}}$ & $29.28^{\mathrm{d}}$ & 0.061 \\
Cellulose & $26.21^{\mathrm{a}}$ & $22.45^{\mathrm{e}}$ & $22.95^{\mathrm{c}}$ & $23.78^{\mathrm{b}}$ & $22.91^{\mathrm{c}}$ & $23.74^{\mathrm{b}}$ & 0.052 \\
Product Recovery\% & & $60.00^{\mathrm{b}}$ & $61.25^{\mathrm{a}}$ & $57.50^{\mathrm{d}}$ & $58.25^{\mathrm{c}}$ & $55.00^{\mathrm{e}}$ & 0.034 \\
\hline
\end{tabular}

Means with different letters with each column are significantly different $(P \leq 0.01)$.

$T$ (1): untreated SBP. T (2): SBP inoculated with S. cerevisiae. T (3): SBP inoculated with T. viride. T (4): SBP inoculated with A. orsa. T(5): SBP inoculated with C. cellulasea and T (6): SBP inoculated with A. xylinum.

The lowest content of cellulose and hemicellulose for treated SBP and OC refers to that biological treatments decreased $\mathrm{CF}$ content and cell wall constituents (NDF, ADF and ADL), the difference between USBP and other treatments in CF content was 4.42 for T2 and T3; 3.36 for T4; 4.38 for T5 and 4.22 for T6, while the decrease in CF content was about 10.01, 7.92, 7.05, 5.07 and 1.77 for T9, T8, T10, T11 and T12; respectively for treated OC than UOC. This decrease probably due to breaking off gross linkage between lignin and cell wall component and solubilizing of cell wall contents (mainly hemicellulose). The best $(\mathrm{P} \leq 0.01)$ product recovery was for $T$. viride followed by $S$. cerevisiae then $C$. cellulasea, while the lowest $(\mathrm{P} \leq 0.01)$ product recovery was for $A$. xylinum followed by A. orsa.

As for second metabolites compounds, the data of Table (3) showed that USBP and biological treated SBP didn't contain any condensed tannins, alkaloids, flavonoids and saponins, while UOC had a considerable content of them but it didn't contain any saponins. Biological treatments for OC significantly $(\mathrm{P} \leq 0.01)$ decreased second metabolites compounds content $T$. viride (T9) had the most decrease. Condensed tannins decreased by $83.15,81.05,78.95$ and $76.84 \%$; respectively for T9, T8 and 
T10, T11 and T12. Alkaloids decreased by 76.09, 65.22, 59.18, 58.69 and 54.35 \%. Flavonoids decreased by $65.44,59.56,47.79,38.34$ and $38.23 \%$, respectively for T9, T8 and T10, T11 and T12. The content of condensed tannins in OC in the present study are slightly more than those obtained by Abdou (2017) but much less than those obtained by Salama (2013) who reported $11.09 \%$ as a level of total tannins. Chemical composition of OC varied according to type of OC, oil extraction and stage of maturity of the fruit.

Table (2): Effect of treatments on chemical composition, cell wall constituents and product recovery (\%) of olive cake during laboratorial experiment.

\begin{tabular}{lccccccc}
\hline & \multicolumn{7}{c}{ Treatment } \\
\cline { 2 - 7 } Item \% & T7 & T8 & T9 & T10 & T11 & T12 & \pm SE \\
\hline DM & $92.53^{\mathrm{e}}$ & $96.24^{\mathrm{a}}$ & $96.28^{\mathrm{a}}$ & $95.30^{\mathrm{b}}$ & $93.82^{\mathrm{c}}$ & $93.50^{\mathrm{d}}$ & 0.025 \\
OM & $86.54^{\mathrm{e}}$ & $88.14^{\mathrm{a}}$ & $87.83^{\mathrm{b}}$ & $87.60^{\mathrm{c}}$ & $87.34^{\mathrm{c}}$ & $86.88^{\mathrm{d}}$ & 0.025 \\
Ash & $13.46^{\mathrm{a}}$ & $11.86^{\mathrm{f}}$ & $12.17^{\mathrm{e}}$ & $12.40^{\mathrm{d}}$ & $12.66^{\mathrm{c}}$ & $13.12^{\mathrm{b}}$ & 0.025 \\
EE & $7.34^{\mathrm{e}}$ & $8.73^{\mathrm{a}}$ & $8.76^{\mathrm{a}}$ & $8.56^{\mathrm{b}}$ & $8.41^{\mathrm{c}}$ & $8.34^{\mathrm{d}}$ & 0.016 \\
CP & $6.88^{\mathrm{f}}$ & $9.18^{\mathrm{b}}$ & $9.54^{\mathrm{a}}$ & $8.95^{\mathrm{c}}$ & $8.20^{\mathrm{d}}$ & $7.71^{\mathrm{e}}$ & 0.021 \\
CF & $24.27^{\mathrm{a}}$ & $16.35^{\mathrm{e}}$ & $14.26^{\mathrm{f}}$ & $17.22^{\mathrm{d}}$ & $19.20^{\mathrm{c}}$ & $22.50^{\mathrm{b}}$ & 0.023 \\
NFE & $48.05^{\mathrm{f}}$ & $53.88^{\mathrm{b}}$ & $55.27^{\mathrm{a}}$ & $52.87^{\mathrm{c}}$ & $51.53^{\mathrm{d}}$ & $48.33^{\mathrm{e}}$ & 0.022 \\
NFC & $10.02^{\mathrm{f}}$ & $12.69^{\mathrm{b}}$ & $17.03^{\mathrm{a}}$ & $12.27^{\mathrm{c}}$ & $11.78^{\mathrm{d}}$ & $11.01^{\mathrm{e}}$ & 0.021 \\
Cell wall constituents\% & & & & & & & \\
NDF & $62.30^{\mathrm{a}}$ & $57.54^{\mathrm{e}}$ & $52.50^{\mathrm{f}}$ & $57.82^{\mathrm{d}}$ & $58.95^{\mathrm{c}}$ & $59.82^{\mathrm{b}}$ & 0.023 \\
ADF & $48.70^{\mathrm{a}}$ & $45.87^{\mathrm{e}}$ & $40.70^{\mathrm{f}}$ & $46.64^{\mathrm{d}}$ & $47.12^{\mathrm{c}}$ & $47.50^{\mathrm{b}}$ & 0.061 \\
ADL & $36.30^{\mathrm{a}}$ & $24.46^{\mathrm{e}}$ & $22.45^{\mathrm{f}}$ & $24.87^{\mathrm{d}}$ & $28.62^{\mathrm{c}}$ & $30.12^{\mathrm{b}}$ & 0.015 \\
Hemicellulose & $13.60^{\mathrm{a}}$ & $11.67^{\mathrm{d}}$ & $11.80^{\mathrm{c}}$ & $11.18^{\mathrm{e}}$ & $11.83^{\mathrm{c}}$ & $12.32^{\mathrm{b}}$ & 0.061 \\
Cellulose & $12.40^{\mathrm{d}}$ & $21.41^{\mathrm{a}}$ & $18.25^{\mathrm{b}}$ & $21.77^{\mathrm{a}}$ & $18.50^{\mathrm{b}}$ & $17.38^{\mathrm{c}}$ & 0.052 \\
Product Recovery\% & & $53.00^{\mathrm{b}}$ & $54.33^{\mathrm{a}}$ & $45.50^{\mathrm{d}}$ & $47.25^{\mathrm{c}}$ & $45.38^{\mathrm{e}}$ & 0.034 \\
\hline
\end{tabular}

Means with different letters with each column are significantly different $(P \leq 0.01)$.

$T$ (7): untreated OC. T (8): OC inoculated with S. cerevisiae. T (9): OC inoculated with T. viride. T (10): OC inoculated with A. orsa. T (11): OC inoculated with C. cellulasea and T (12): OC inoculated with A. xylinum.

Similar results were found by Israilides et al. (1994) who found that CP content of SBP was increased from 9.96 to $19.50 \%$ by fungal treatments. El-Ashry et al. (2003) and Kholif et al. (2005) indicated that the fungal treatment led to increase CP and decreased CF and OM content. Also, Abedo et al. (2005) found that fungal treatment with $T$. ressei increased the CP content of SBP from 9.94 to $19.37 \%$ and $\mathrm{EE}$ from 0.64 to $0.88 \%$, in contrast, $\mathrm{CF}, \mathrm{ADF}, \mathrm{ADL}$ and cellulose content increased by fungal treatments, while NDF and hemicellulose were decreased.

Table (3): Effect of treatments on condensed tannins, alkaloids, flavonoids and saponins (\%).

\begin{tabular}{lcccc}
\hline & \multicolumn{3}{c}{ Item } \\
\cline { 2 - 5 } Treatment & Condensed tannins & Alkaloids & Flavonoids & Saponins \\
\hline T1 & Nil & Nil & Nil & Nil \\
T7 & $0.95^{\mathrm{a}}$ & $0.46^{\mathrm{a}}$ & $2.72^{\mathrm{a}}$ & Nil \\
T8 & $0.18^{\mathrm{d}}$ & $0.16^{\mathrm{c}}$ & $1.10^{\mathrm{d}}$ & Nil \\
T9 & $0.16^{\mathrm{e}}$ & $0.11^{\mathrm{d}}$ & $0.94^{\mathrm{e}}$ & Nil \\
T10 & $0.18^{\mathrm{d}}$ & $0.19^{\mathrm{bc}}$ & $1.68^{\mathrm{b}}$ & Nil \\
T11 & $0.20^{\mathrm{c}}$ & $0.17^{\mathrm{c}}$ & $1.42^{\mathrm{c}}$ & Nil \\
T12 & $0.22^{\mathrm{b}}$ & $0.21^{\mathrm{b}}$ & $1.65^{\mathrm{b}}$ & Nil \\
\pm SE & 0.052 & 0.060 & 0.052 & 0.000 \\
\hline
\end{tabular}

Means with different letters with each column are significantly different $(P \leq 0.01)$.

T (1): U SBP. T (7): untreated OC. T (8): OC inoculated with S. cerevisiae. T (9): OC inoculated with T. viride. T(10): OC inoculated with A. orsa. T(11): OC inoculated with C. cellulasea. T (12): OC inoculated with A. xylinum.

Gomaa et al. (2016) and Abdou (2017) reported that the supplemented OC with biological treatments reported a higher content of $\mathrm{CP}$ and a lower content of cell wall components and decreased condensed tannins compared to that without biological treatments. It seems that $S$. cerevisiae, T.viride and $C$. cellulasea were more efficient than $A$. orsa and A. xylinum in improving chemical composition of SBP 
and OC. So, the data of the laboratorial experiment suggested using these three biological treatments in in vitro and in vivo trials.

\section{In vitro and in vivo experiments:}

\section{Chemical composition and cell wall constituents:}

Comparison among treatments (Table 4) showed that all biological treatments for SBP and OC increased DM, OM, EE and CP content, the highest $(\mathrm{P} \leq 0.01)$ values were for T3 followed byT4 then T5, respectively. Whereas, ash, $\mathrm{CF}, \mathrm{NFE}$ and NFC were decreased $(\mathrm{P} \leq 0.01)$ in the three treated groups. Untreated group (T2) had the highest values of NDF, ADF and ADL, while it was the lowest content of cellulose and hemicellulose.

Table (4): Effect of treatments on chemical composition and cell wall constituents during in vitro and in vivo experiments.

\begin{tabular}{|c|c|c|c|c|c|c|c|c|}
\hline \multirow[b]{2}{*}{ Items } & \multicolumn{7}{|c|}{ Treatments } & \multirow[b]{2}{*}{$\pm \mathrm{SE}$} \\
\hline & CFM & Hay & $\mathrm{T} 1$ & $\mathrm{~T} 2$ & T3 & $\mathrm{T} 4$ & T5 & \\
\hline \multicolumn{9}{|c|}{ Chemical composition $\%$} \\
\hline DM & 93.80 & 91.24 & $91.60^{\mathrm{c}}$ & $89.34^{\mathrm{d}}$ & $93.61^{\mathrm{a}}$ & $93.59^{\mathrm{a}}$ & $92.75^{\mathrm{b}}$ & 0.023 \\
\hline OM & 92.00 & 88.01 & $89.01^{\mathrm{d}}$ & $88.80^{\mathrm{e}}$ & $90.02^{\mathrm{a}}$ & $89.88^{\mathrm{b}}$ & $89.75^{\mathrm{c}}$ & 0.023 \\
\hline Ash & 8.00 & 11.99 & $10.99^{\mathrm{b}}$ & $11.20^{\mathrm{a}}$ & $9.98^{\mathrm{e}}$ & $10.12^{\mathrm{d}}$ & $10.25^{\mathrm{c}}$ & 0.023 \\
\hline $\mathrm{EE}$ & 3.10 & 2.55 & $2.55^{\mathrm{d}}$ & $2.71^{\mathrm{c}}$ & $4.51^{\mathrm{a}}$ & $4.47^{\mathrm{ab}}$ & $4.35^{\mathrm{b}}$ & 0.018 \\
\hline $\mathrm{CP}$ & 12.49 & 14.00 & $13.55^{\mathrm{c}}$ & $9.33^{\mathrm{d}}$ & $14.53^{\mathrm{a}}$ & $14.45^{\mathrm{a}}$ & $13.95^{\mathrm{b}}$ & 0.022 \\
\hline $\mathrm{CF}$ & 11.32 & 26.61 & $19.47^{\mathrm{b}}$ & $23.31^{\mathrm{a}}$ & $18.60^{\mathrm{c}}$ & $17.90^{\mathrm{d}}$ & $19.56^{\mathrm{b}}$ & 0.024 \\
\hline NFE & 65.09 & 44.85 & $53.44^{\mathrm{a}}$ & $53.45^{\mathrm{a}}$ & $52.38^{\mathrm{c}}$ & $53.03^{\mathrm{b}}$ & $51.89^{\mathrm{d}}$ & 0.022 \\
\hline NFC & 45.43 & 8.50 & $16.50^{\mathrm{a}}$ & $16.20^{\mathrm{a}}$ & $14.99^{\mathrm{b}}$ & $16.62^{\mathrm{a}}$ & $14.94^{\mathrm{b}}$ & 0.022 \\
\hline \multicolumn{9}{|c|}{ Cell wall constituents $\%$} \\
\hline NDF & 30.98 & 62.96 & $56.41^{\mathrm{b}}$ & $60.56^{\mathrm{a}}$ & $56.00^{\mathrm{b}}$ & $54.34^{\mathrm{c}}$ & $56.52^{\mathrm{b}}$ & 0.024 \\
\hline $\mathrm{ADF}$ & 17.75 & 44.44 & $28.74^{\mathrm{d}}$ & $39.00^{\mathrm{a}}$ & $33.00^{\mathrm{b}}$ & $31.46^{\mathrm{c}}$ & $33.64^{\mathrm{b}}$ & 0.064 \\
\hline ADL & 7.82 & 7.13 & $7.42^{\mathrm{e}}$ & $20.92^{\mathrm{a}}$ & $11.28^{\mathrm{c}}$ & $10.62^{\mathrm{d}}$ & $12.73^{\mathrm{b}}$ & 0.019 \\
\hline Hemicellulose & 13.23 & 18.52 & $27.67^{\mathrm{a}}$ & $21.56^{\mathrm{c}}$ & $22.99^{\mathrm{b}}$ & $22.88^{\mathrm{b}}$ & $22.88^{\mathrm{b}}$ & 0.064 \\
\hline Cellulose & 9.93 & 37.31 & $21.32^{\mathrm{a}}$ & $18.08^{\mathrm{b}}$ & $21.73^{\mathrm{a}}$ & $20.84^{\mathrm{a}}$ & $20.91^{\mathrm{a}}$ & 0.054 \\
\hline \multicolumn{9}{|c|}{ Second metabolites compounds $\%$} \\
\hline Condensed tannins & Nil & 0.5 & $0.11^{\mathrm{e}}$ & $0.63^{\mathrm{a}}$ & $0.22^{\mathrm{c}}$ & $0.19^{\mathrm{d}}$ & $0.29^{\mathrm{b}}$ & 0.064 \\
\hline Alkaloids & Nil & Nil & $\mathrm{Nil}^{\mathrm{e}}$ & $0.16^{\mathrm{a}}$ & $0.09^{c}$ & $0.07^{\mathrm{d}}$ & $0.10^{\mathrm{b}}$ & 0.052 \\
\hline Flavonoids & Nil & 4.12 & $1.00^{\mathrm{b}}$ & $2.10^{\mathrm{a}}$ & $1.00^{\mathrm{b}}$ & $0.88^{\mathrm{c}}$ & $1.00^{\mathrm{b}}$ & 0.068 \\
\hline Saponins & Nil & Nil & Nil & Nil & Nil & Nil & Nil & 0.000 \\
\hline
\end{tabular}

Means with different letters with each column are significantly different $(P \leq 0.01)$.

$T$ (1): Concentrate feed mixture (CFM) + berseem hay $(B H)$ (control). T (2): CFM contains $40 \%$ untreated SBP + $30 \%$ untreated OC+BH. T(3): CFM contains $40 \%$ SBP $+30 \%$ OC (treated with S. cerevisiae) $+B H . T(4): C F M$ contains $40 \% S B P+30 \%$ OC (treated with T. viride) $+B H . T$ (5): CFM contains $40 \% S B P+30 \%$ OC (treated with C. cellulasea) $+B H$.

The increase of $\mathrm{CP}$ content by biological treatments may be due to the increase in rumen microorganisms which consume $\mathrm{CP}$ of the diet to convert it into microbial protein. While, the decrease of CF content may be due to cellulolytic bacteria which secreted cellulase enzymes to degrade crude fiber, or due to the utilization of CF by fungi for their growth.

\section{In vitro nutrients disappearance:}

The data of Table (5) revealed that biological treatments increased $(\mathrm{P} \leq 0.01) \mathrm{DM}, \mathrm{OM}, \mathrm{EE}, \mathrm{CP}, \mathrm{CF}$, NFE and NDF disappearance more than $\mathrm{T} 1$ and $\mathrm{T} 2$. The difference was not significant $(\mathrm{P} \leq 0.01)$ between $\mathrm{T} 2$ and $\mathrm{T} 1$ in $\mathrm{CP}$ disappearance value, although, T1 had the lowest disappearance value of $\mathrm{CF}$ followed by $\mathrm{T} 2$. T1, T3, T4 and $\mathrm{T} 5$ had no significant difference $(\mathrm{P} \leq 0.01)$ for $\mathrm{ADF}$, ADL, cellulose and hemicellulose disappearance values. Similar results were obtained by El-Ashry et al. (2003) who found that biological treatments for poor quality roughages by $T$. viride, P. funiculosium and S. cerevisiae increased DM and OM in vitro disappearance. Also, Aziz (2014) found that rations contained $30 \%$ SBP treated with fungi, yeast or bacteria increased $(\mathrm{P} \leq 0.01) \mathrm{DM}, \mathrm{OM}, \mathrm{EE}, \mathrm{CP}, \mathrm{CF}, \mathrm{NFE}, \mathrm{NDF}, \mathrm{ADF}, \mathrm{ADL}$, cellulose and hemicellulose disappearance more than USBP and control. 
Table (5): Effect of treatments on dry matter, organic matter and other nutrients disappearance (\%) during in vitro experiment.

\begin{tabular}{|c|c|c|c|c|c|c|}
\hline \multirow[b]{2}{*}{ Item } & \multicolumn{5}{|c|}{ Treatment } & \multirow[b]{2}{*}{$\pm \mathrm{SE}$} \\
\hline & $\mathrm{T} 1$ & $\mathrm{~T} 2$ & T3 & $\mathrm{T} 4$ & $\mathrm{~T} 5$ & \\
\hline DM & $63.02^{\mathrm{d}}$ & $60.75^{\mathrm{e}}$ & $70.05^{\mathrm{b}}$ & $71.62^{\mathrm{a}}$ & $67.93^{c}$ & 0.245 \\
\hline $\mathrm{OM}$ & $63.44^{\mathrm{e}}$ & $65.19^{\mathrm{d}}$ & $70.62^{\mathrm{c}}$ & $72.74^{\mathrm{b}}$ & $74.42^{\mathrm{a}}$ & 0.264 \\
\hline $\mathrm{EE}$ & $73.05^{\mathrm{b}}$ & $54.84^{\mathrm{e}}$ & $69.35^{\mathrm{c}}$ & $66.34^{\mathrm{d}}$ & $75.72^{a}$ & 0.153 \\
\hline $\mathrm{CP}$ & $59.06^{c}$ & $59.42^{\mathrm{c}}$ & $77.97^{\mathrm{a}}$ & $77.23^{\mathrm{b}}$ & $77.33^{\mathrm{ab}}$ & 0.204 \\
\hline $\mathrm{CF}$ & $78.36^{\mathrm{e}}$ & $83.91^{\mathrm{b}}$ & $85.10^{\mathrm{a}}$ & $82.02^{\mathrm{d}}$ & $82.60^{c}$ & 0.154 \\
\hline NFE & $57.50^{d}$ & $66.74^{\mathrm{b}}$ & $66.07^{\mathrm{c}}$ & $71.48^{\mathrm{a}}$ & $71.24^{\mathrm{a}}$ & 0.090 \\
\hline NFC & $6.15^{\mathrm{e}}$ & $13.17^{\mathrm{a}}$ & $7.07^{\mathrm{d}}$ & $10.59^{\mathrm{b}}$ & $9.72^{\mathrm{c}}$ & 0.019 \\
\hline NDF & $58.28^{c}$ & $65.72^{\mathrm{b}}$ & $64.18^{\mathrm{b}}$ & $69.05^{\mathrm{a}}$ & $71.25^{\mathrm{a}}$ & 7.107 \\
\hline $\mathrm{ADF}$ & $75.30^{\mathrm{a}}$ & $63.19^{\mathrm{b}}$ & $72.83^{a}$ & $71.67^{\mathrm{a}}$ & $75.88^{a}$ & 1.469 \\
\hline $\mathrm{ADL}$ & $83.61^{\mathrm{a}}$ & $77.89^{\mathrm{b}}$ & $80.64^{\mathrm{ab}}$ & $78.31^{\mathrm{b}}$ & $83.34^{\mathrm{a}}$ & 1.382 \\
\hline Cellulose & $68.10^{\mathrm{ab}}$ & $58.07^{\mathrm{b}}$ & $76.04^{\mathrm{a}}$ & $76.18^{\mathrm{a}}$ & $76.49^{a}$ & 4.198 \\
\hline Hemicellulose & $70.03^{\mathrm{a}}$ & $44.73^{\mathrm{b}}$ & $68.70^{\mathrm{a}}$ & $68.64^{\mathrm{a}}$ & $70.70^{\mathrm{a}}$ & 3.036 \\
\hline
\end{tabular}

Means with different letters with each column are significantly different $(P \leq 0.01)$.

\section{In vivo experiment:}

\section{Feed intake, digestibility coefficients and nutritive values:}

The data of Table (6) indicated no significant $(\mathrm{P} \leq 0.01)$ difference among biological treatments and control group, as they had higher values than $\mathrm{T} 2$. Biological treatments significantly increased $(\mathrm{P} \leq 0.01)$ digestibility coefficients of DM, OM, EE, CP, CF, NFE, NFC, NDF, ADF, ADL, cellulose and hemicellulose more than control and untreated groups, as T4 improved all nutrients digestibility coefficients followed by T3 then T5, T1 and T2, with no significant difference among T4, T3, T5 and T1 for NFE, NFC, cellulose and hemicellulose digestibility coefficients. Khampa et al. (2009) reported that higher nutrients digestibility as a result of yeast supplementation could be related to the microbial activities which solubilizing of carbohydrate esters of phenolic monomers in the cell wall. The reduction of the digestibility coefficients for untreated group (T2) could be attributed to the high level of fiber fraction. The estimated digestibilities were in the range reported by Aziz (2014) for sheep fed SBP or by Abdou (2017) for sheep fed OC.

Biological treatments increased ( $\mathrm{P} \leq 0.01) \mathrm{TDN}$ and DCP $(\mathrm{g} / \mathrm{h} / \mathrm{d}, \mathrm{g} / \mathrm{kg} \mathrm{BW}$ and $\%$ of DMI), also, T1 not significantly differed with $\mathrm{T} 4$ and $\mathrm{T} 5$ for $\mathrm{TDN}$ values, while, $\mathrm{T} 2$ had the lowest $(\mathrm{P} \leq 0.01)$ values. Biologically treated groups T3 and T4 were more efficient in TDN and DCP values with no significant $(\mathrm{P} \leq 0.01)$ difference, as T3 and T4 increased TDN (\% of DMI) value about $5.5 \%$ more than $\mathrm{T} 1$ and about $7.5 \%$ more than T2, while, DCP increased by 1.8 and $1.75 \%$ of DMI more than T1 and 4.49 and $4.44 \%$ of DMI more than T2 for T4 followed by T3, respectively. T3 had the highest value of metabolic energy (Mcal/ kg DM) followed by T4 then T1 with no significant difference among the three treatments, while T5 increased metabolic energy more than T2. It seems that inclusion of SBP and OC by $40 \%$ and $30 \%$ in CFM decreased feed costs, untreated group had the lowest feed costs followed by biological treatments.

The results of TDN and DCP reflected the values obtained for rations digestibility, these improvements are may associated with the increased digestion in fibrous materials particularly hemicellulose in addition to the increased bacterial digestion of cell wall content.

This result come online with those obtained by Kholif et al. (2005) and Aziz (2009) who reported slight increase in DMI and improvement of DM, CP and CF digestibility coefficients over a wide range of low-quality roughages treated by biological treatments. Allam et al. (2006) reported that treated SBP with T. viride and S. cerevisiae increased DM, OM, CF, NDF, ADF, ADL and cellulose digestibilities. Also, Aboul-Fotouh et al. (2013) found that treatment of OC with yeast increased digestibility coefficient and nutritive values. Aziz (2014 and 2015) found an increase ( $\mathrm{P} \leq 0.01)$ in digestibility coefficients, TDN, DCP and ME for sheep fed biologically treated SBP. Abdou (2017) found that sheep fed biologically treated OC recorded higher values of feed intake and improved all nutrients digestibilities, TDN and DCP than those fed control. 
Table (6): Effect of treatments on nutrient digestibility and nutritive value of the experimental rations.

\begin{tabular}{|c|c|c|c|c|c|c|}
\hline \multirow[b]{2}{*}{ Item } & \multicolumn{5}{|c|}{ Treatment } & \multirow[b]{2}{*}{$\pm \mathrm{SE}$} \\
\hline & $\mathrm{T} 1$ & $\mathrm{~T} 2$ & T3 & $\mathrm{T} 4$ & $\mathrm{~T} 5$ & \\
\hline Number of animals & 4 & 4 & 4 & 4 & 4 & \\
\hline Live body weight, $\mathrm{kg}$ & 47.50 & 47.00 & 46.87 & 46.62 & 46.50 & 1.550 \\
\hline Feed intake $\mathrm{g} / \mathrm{h} / \mathrm{d}$ & $1047.68^{\mathrm{a}}$ & $923.00^{\mathrm{b}}$ & $1047.81^{\mathrm{a}}$ & $1012.68^{\mathrm{a}}$ & $1026.87^{\mathrm{a}}$ & 21.22 \\
\hline \multicolumn{7}{|l|}{ Digestibility\%: } \\
\hline DM & $66.07^{\mathrm{c}}$ & $62.14^{\mathrm{d}}$ & $70.16^{\mathrm{a}}$ & $70.39^{\mathrm{a}}$ & $68.15^{\mathrm{b}}$ & 0.562 \\
\hline $\mathrm{OM}$ & $66.06^{c}$ & $63.81^{\mathrm{d}}$ & $70.84^{\mathrm{a}}$ & $70.55^{\mathrm{a}}$ & $68.20^{\mathrm{b}}$ & 0.691 \\
\hline $\mathrm{EE}$ & $70.99^{b}$ & $66.20^{\mathrm{d}}$ & $72.03^{\mathrm{ab}}$ & $73.05^{\mathrm{a}}$ & $68.72^{\mathrm{c}}$ & 0.431 \\
\hline $\mathrm{CP}$ & $64.98^{c}$ & $62.61^{\mathrm{d}}$ & $72.39^{\mathrm{a}}$ & $72.98^{\mathrm{a}}$ & $69.79^{\mathrm{b}}$ & 0.357 \\
\hline $\mathrm{CF}$ & $63.84^{c}$ & $61.76^{\mathrm{d}}$ & $66.81^{\mathrm{b}}$ & $69.07^{\mathrm{a}}$ & $65.52^{\mathrm{b}}$ & 0.525 \\
\hline NFE & $66.68^{\mathrm{a}}$ & $63.96^{\mathrm{a}}$ & $67.61^{\mathrm{a}}$ & $67.04^{\mathrm{a}}$ & $52.65^{\mathrm{b}}$ & 2.270 \\
\hline NFC & $84.26^{\mathrm{ab}}$ & $83.31^{\mathrm{b}}$ & $88.13^{\mathrm{ab}}$ & $85.05^{\mathrm{ab}}$ & $96.18^{\mathrm{a}}$ & 3.752 \\
\hline $\mathrm{NDF}$ & $58.82^{\mathrm{d}}$ & $57.80^{\mathrm{d}}$ & $62.53^{\mathrm{b}}$ & $64.75^{\mathrm{a}}$ & $60.37^{c}$ & 0.370 \\
\hline $\mathrm{ADF}$ & $50.65^{\mathrm{b}}$ & $52.21^{\mathrm{b}}$ & $60.04^{\mathrm{a}}$ & $60.79^{a}$ & $58.96^{\mathrm{a}}$ & 0.637 \\
\hline $\mathrm{ADL}$ & $54.95^{\mathrm{d}}$ & $57.00^{\mathrm{cd}}$ & $60.38^{b}$ & $63.44^{\mathrm{a}}$ & $58.29^{\mathrm{bc}}$ & 0.942 \\
\hline Cellulose & $61.21^{\mathrm{a}}$ & $55.27^{\mathrm{b}}$ & $62.08^{\mathrm{a}}$ & $63.06^{\mathrm{a}}$ & $62.87^{\mathrm{a}}$ & 0.976 \\
\hline Hemicellulose & $59.89^{\mathrm{bc}}$ & $61.76^{\mathrm{bc}}$ & $64.13^{\mathrm{ab}}$ & $67.28^{\mathrm{a}}$ & $58.90^{\mathrm{c}}$ & 1.555 \\
\hline \multicolumn{7}{|l|}{ Nutritive value: } \\
\hline \multicolumn{7}{|l|}{ TDN: } \\
\hline $\mathrm{g} / \mathrm{h} / \mathrm{d}$ & $584.46^{\mathrm{b}}$ & $497.14^{\mathrm{c}}$ & $643.40^{\mathrm{a}}$ & $622.51^{\mathrm{ab}}$ & $539.07^{\mathrm{bc}}$ & 18.256 \\
\hline $\mathrm{g} / \mathrm{kg} \mathrm{BW}$ & $12.39^{\mathrm{ab}}$ & $10.58^{c}$ & $13.82^{\mathrm{a}}$ & $13.40^{\mathrm{a}}$ & $11.61^{\mathrm{bc}}$ & 0.681 \\
\hline$\%$ of DMI & $55.82^{\mathrm{b}}$ & $53.83^{\mathrm{b}}$ & $61.32^{\mathrm{a}}$ & $61.59^{\mathrm{a}}$ & $52.49^{\mathrm{b}}$ & 1.260 \\
\hline \multicolumn{7}{|l|}{ DCP: } \\
\hline $\mathrm{g} / \mathrm{h} / \mathrm{d}$ & $84.46^{c}$ & $49.67^{\mathrm{d}}$ & $102.92^{\mathrm{a}}$ & $99.97^{\mathrm{a}}$ & $92.72^{\mathrm{b}}$ & 2.164 \\
\hline $\mathrm{g} / \mathrm{kg} \mathrm{BW}$ & $1.79^{\mathrm{b}}$ & $1.05^{\mathrm{b}}$ & $2.20^{\mathrm{a}}$ & $2.15^{\mathrm{a}}$ & $1.99^{\mathrm{ab}}$ & 0.092 \\
\hline$\%$ of DMI & $8.07^{\mathrm{c}}$ & $5.38^{\mathrm{d}}$ & $9.82^{\mathrm{a}}$ & $9.87^{\mathrm{a}}$ & $9.03^{\mathrm{b}}$ & 0.357 \\
\hline $\mathrm{ME}(\mathrm{Mcal} / \mathrm{kg} \mathrm{DM}) *$ & $21.15^{\mathrm{ab}}$ & $17.99^{\mathrm{c}}$ & $23.28^{\mathrm{a}}$ & $22.53^{\mathrm{a}}$ & $19.51^{\mathrm{bc}}$ & 0.660 \\
\hline Feed costs L.E. $/ \mathrm{kg}$ & 4.9 & 3.73 & 3.93 & 3.93 & 3.93 & \\
\hline
\end{tabular}

Means with different letters with each row are significantly different $(P \leq 0.01)$.

$M E=$ Metabolizable energy $=T D N \mathrm{~g} /$ head $\times 3.6$ (Church and Pond, 1982).

The price of one $\mathrm{kg}$ of CFM, BH, SBP and OC were 5.5, 4, 4, 1 L.E., respectively. The price of one liter of fungi or bacteria or yeast $=200$ L.E.

\section{Nitrogen utilization:}

Table (7) clarified that biological treatments increased $(\mathrm{P} \leq 0.01)$ nitrogen intake $(\mathrm{NI})$ and digested nitrogen $(\mathrm{DN})$ values more than control and untreated groups. The highest $(\mathrm{P} \leq 0.01) \mathrm{NI}(\mathrm{g} / \mathrm{h} / \mathrm{d})$ and $\mathrm{DN}$ $(\mathrm{g} / \mathrm{h} / \mathrm{d}$ and $\%$ of NI) were for T3 and T4 followed by T5 with no significant difference followed by control, while untreated group was the less one. NI (g/h/d) for T3, T4 and T5 were more than T1by 1.94 , 1.11 and 0.46 , respectively, while they were more than $\mathrm{T} 2$ by $10.06,9.23$ and 8.58 , respectively.

Control had higher $(\mathrm{P} \leq 0.01)$ fecal and urinary nitrogen excretion $(\mathrm{g} / \mathrm{h} / \mathrm{d})$ more than untreated and biological treatments, while untreated group (T2) was the lowest one as $\mathrm{g} / \mathrm{h} / \mathrm{d}$, although it was the highest one $(\mathrm{P} \leq 0.01)$ as $\%$ of NI. It is clear that biological treatments increased $(\mathrm{P} \leq 0.01)$ nitrogen balance $(\mathrm{g} / \mathrm{h} / \mathrm{d}$, $\%$ of NI and \% of DN) more than control and untreated groups, T3 and T4 had the highest values with no significant difference followed by T5, while untreated group (T2) had the lowest values, control group (T1) was moderated values between T2 and biological treatments. Nitrogen balance values for T4, T3 and T5 were more than T1 by $9.2,8.51$ and $5.2 \%$ of NI, respectively, while they were more than T2 about $12.07,11.38$ and $8.07 \%$ of NI, respectively. The improvement of nitrogen balance with biological treatment due to less nitrogen excretion or may be because of the improvement in rumen fermentation especially ruminal ammonia, NPN, total nitrogen and true protein nitrogen. This result was in agreement with results obtained by Aziz (2009) who reported that nitrogen balance improved by biological treatments of agriculture by-products. Allam et al. (2006) reported that biologically treated SBP with $T$. viride and S. cerevisiae had the highest value of nitrogen balance. Aziz (2014 and 2015) found an increase in nitrogen balance of sheep and goats fed biologically treated SBP. 
Table (7): Nitrogen utilization for Barki rams fed experimental treatments.

\begin{tabular}{|c|c|c|c|c|c|c|}
\hline \multirow[b]{2}{*}{ Item } & \multicolumn{5}{|c|}{ Treatment } & \multirow[b]{2}{*}{$\pm \mathrm{SE}$} \\
\hline & $\mathrm{T} 1$ & $\mathrm{~T} 2$ & $\mathrm{~T} 3$ & $\mathrm{~T} 4$ & T5 & \\
\hline Nitrogen intake $(\mathrm{g} / \mathrm{h} / \mathrm{d})$ & $20.80^{\mathrm{b}}$ & $12.68^{c}$ & $22.74^{\mathrm{a}}$ & $21.91^{\mathrm{ab}}$ & $21.26^{\mathrm{ab}}$ & 0.479 \\
\hline Digested nitrogen $(\mathrm{g} / \mathrm{h} / \mathrm{d})$ & $13.51^{\mathrm{c}}$ & $7.95^{\mathrm{d}}$ & $16.46^{\mathrm{a}}$ & $15.99^{\mathrm{a}}$ & $14.83^{\mathrm{b}}$ & 0.346 \\
\hline$\%$ of $\mathrm{N}$ intake & $64.98^{c}$ & $62.61^{\mathrm{d}}$ & $72.39^{a}$ & $72.98^{a}$ & $69.79^{\mathrm{b}}$ & 0.357 \\
\hline Fecal nitrogen (g/h/d) & $7.28^{\mathrm{a}}$ & $4.73^{c}$ & $6.28^{\mathrm{b}}$ & $5.91^{\mathrm{b}}$ & $6.42^{\mathrm{b}}$ & 0.163 \\
\hline$\%$ of $\mathrm{N}$ intake & $35.01^{\mathrm{b}}$ & $37.38^{\mathrm{a}}$ & $27.60^{\mathrm{d}}$ & $27.01^{\mathrm{d}}$ & $30.20^{\mathrm{c}}$ & 0.357 \\
\hline Urinary nitrogen $(\mathrm{g} / \mathrm{h} / \mathrm{d})$ & $0.66^{\mathrm{a}}$ & $0.47^{\mathrm{b}}$ & $0.47^{\mathrm{b}}$ & $0.43^{\mathrm{b}}$ & $0.60^{\mathrm{a}}$ & 0.032 \\
\hline$\%$ of $\mathrm{N}$ intake & $3.21^{\mathrm{ab}}$ & $3.70^{\mathrm{a}}$ & $2.10^{\mathrm{c}}$ & $2.01^{\mathrm{c}}$ & $2.82^{\mathrm{b}}$ & 0.189 \\
\hline Total $\mathrm{N}$ excretion $(\mathrm{g} / \mathrm{h} / \mathrm{d})$ & $7.95^{\mathrm{a}}$ & $5.20^{\mathrm{d}}$ & $6.75^{\mathrm{bc}}$ & $6.35^{\mathrm{c}}$ & $7.02^{\mathrm{b}}$ & 0.157 \\
\hline$\%$ of $\mathrm{N}$ intake & $38.22^{\mathrm{b}}$ & $41.09^{\mathrm{a}}$ & $29.71^{\mathrm{d}}$ & $29.02^{\mathrm{d}}$ & $33.03^{c}$ & 0.446 \\
\hline Nitrogen balance $(\mathrm{g} / \mathrm{h} / \mathrm{d})$ & $12.85^{\mathrm{c}}$ & $7.48^{\mathrm{d}}$ & $15.99^{\mathrm{a}}$ & $15.55^{\mathrm{a}}$ & $14.23^{\mathrm{b}}$ & 0.361 \\
\hline$\%$ of $\mathrm{N}$ intake & $61.77^{\mathrm{c}}$ & $58.90^{\mathrm{d}}$ & $70.28^{\mathrm{a}}$ & $70.97^{\mathrm{a}}$ & $66.97^{\mathrm{b}}$ & 0.446 \\
\hline$\%$ of digested $\mathrm{N}$ & $95.06^{\mathrm{c}}$ & $94.07^{\mathrm{d}}$ & $97.09^{\mathrm{a}}$ & $97.24^{\mathrm{a}}$ & $95.96^{\mathrm{b}}$ & 0.285 \\
\hline
\end{tabular}

\section{Rumen parameters and microbial protein:}

Ruminal pH, volatile fatty acids and molar proportion of individual VFA's (\%):

The data of Table (8) indicated that biological treatments significantly increased $(\mathrm{P} \leq 0.01)$ ruminal $\mathrm{pH}$

Table (8): Effect of experimental treatments on ruminal pH, total volatile fatty acids and molar proportion of individual VFA's.

\begin{tabular}{|c|c|c|c|c|c|c|c|c|}
\hline \multirow[b]{2}{*}{ Item } & \multirow[b]{2}{*}{ Time } & \multicolumn{6}{|c|}{ Treatment } & \multirow{2}{*}{$\begin{array}{l}\text { Overall mean } \\
\pm \text { SE }\end{array}$} \\
\hline & & $\mathrm{T} 1$ & $\mathrm{~T} 2$ & T3 & $\mathrm{T} 4$ & T5 & $\pm \mathrm{SE}$ & \\
\hline \multirow[t]{4}{*}{$\mathrm{pH}$} & 0 & 7.06 & 6.90 & 7.48 & 7.25 & 7.16 & 0.044 & $7.17^{\mathrm{a}} \pm 0.020$ \\
\hline & 2 & 6.17 & 6.18 & 6.59 & 6.42 & 6.31 & 0.044 & $6.33^{c} \pm 0.020$ \\
\hline & 4 & 6.12 & 6.10 & 6.52 & 6.34 & 6.24 & 0.044 & $6.26^{\mathrm{d}} \pm 0.020$ \\
\hline & 6 & 6.42 & 6.26 & 6.76 & 6.58 & 6.52 & 0.044 & $6.50^{\mathrm{b}} \pm 0.020$ \\
\hline Overall mean & & $6.44^{\mathrm{d}}$ & $6.36^{\mathrm{e}}$ & $6.84^{\mathrm{a}}$ & $6.64^{b}$ & $6.56^{c}$ & 0.022 & \\
\hline TVFA's $\quad(\mathrm{ml}$ & 0 & 6.59 & 6.22 & 7.09 & 6.86 & 6.36 & 0.198 & $6.62^{\mathrm{d}} \pm 0.088$ \\
\hline equiv/100 & 2 & 7.27 & 7.00 & 8.41 & 8.25 & 8.52 & 0.198 & $7.89^{c} \pm 0.088$ \\
\hline \multirow[t]{2}{*}{ R.L) } & 4 & 8.21 & 8.03 & 9.44 & 9.44 & 9.84 & 0.198 & $8.99^{\mathrm{a}} \pm 0.088$ \\
\hline & 6 & 7.86 & 7.06 & 9.00 & 8.84 & 9.11 & 0.198 & $8.37^{b} \pm 0.088$ \\
\hline $\begin{array}{l}\text { Overall mean } \\
\text { MpTVFA's\%*: }\end{array}$ & & $7.48^{b}$ & $7.08^{c}$ & $8.48^{\mathrm{a}}$ & $8.34^{\mathrm{a}}$ & $8.46^{\mathrm{a}}$ & 0.099 & \\
\hline \multirow[t]{4}{*}{ Acetic } & 0 & 32.10 & 31.41 & 36.52 & 35.06 & 34.80 & 0.243 & $33.98^{\mathrm{d}} \pm 0.108$ \\
\hline & 2 & 34.76 & 34.67 & 39.23 & 38.74 & 37.88 & 0.243 & $37.05^{\mathrm{c}} \pm 0.108$ \\
\hline & 4 & 37.84 & 36.67 & 41.64 & 40.52 & 40.52 & 0.243 & $39.44^{\mathrm{a}} \pm 0.108$ \\
\hline & 6 & 35.85 & 34.74 & 40.32 & 39.33 & 38.97 & 0.243 & $37.84^{\mathrm{b}} \pm 0.108$ \\
\hline Overall mean & & $35.14^{\mathrm{d}}$ & $34.37^{\mathrm{e}}$ & $39.42^{\mathrm{a}}$ & $38.41^{\mathrm{b}}$ & $38.04^{\mathrm{c}}$ & 0.121 & \\
\hline \multirow[t]{4}{*}{ Propionic } & 0 & 16.24 & 15.87 & 19.45 & 20.22 & 18.11 & 0.181 & $17.98^{\mathrm{d}} \pm 0.081$ \\
\hline & 2 & 18.10 & 16.38 & 22.68 & 22.69 & 20.55 & 0.181 & $20.08^{c} \pm 0.081$ \\
\hline & 4 & 20.44 & 17.90 & 25.50 & 22.07 & 22.70 & 0.181 & $21.72^{\mathrm{a}} \pm 0.081$ \\
\hline & 6 & 18.94 & 16.49 & 23.77 & 22.78 & 21.39 & 0.181 & $20.67^{\mathrm{b}} \pm 0.081$ \\
\hline Overall mean & & $18.43^{\mathrm{d}}$ & $16.66^{\mathrm{e}}$ & $22.85^{\mathrm{a}}$ & $21.94^{\mathrm{b}}$ & $20.68^{c}$ & 0.090 & \\
\hline \multirow[t]{4}{*}{ Butyric } & 0 & 14.09 & 14.02 & 16.53 & 15.71 & 13.99 & 0.295 & $14.87^{c} \pm 0.132$ \\
\hline & 2 & 14.82 & 14.87 & 17.66 & 17.73 & 15.35 & 0.295 & $16.09^{\mathrm{b}} \pm 0.132$ \\
\hline & 4 & 16.45 & 16.35 & 18.40 & 17.71 & 16.26 & 0.295 & $17.03^{\mathrm{a}} \pm 0.132$ \\
\hline & 6 & 15.91 & 14.94 & 18.25 & 18.32 & 15.94 & 0.295 & $16.67^{\mathrm{a}} \pm 0.132$ \\
\hline Overall mean & & $15.32^{\mathrm{b}}$ & $15.04^{\mathrm{b}}$ & $17.71^{\mathrm{a}}$ & $17.37^{\mathrm{a}}$ & $15.38^{\mathrm{b}}$ & 0.147 & \\
\hline \multirow[t]{4}{*}{$\mathrm{A} / \mathrm{P}$ ratio } & 0 & 1.97 & 1.98 & 1.97 & 1.73 & 2.01 & 0.063 & $1.93^{\mathrm{ab}} \pm 0.028$ \\
\hline & 2 & 1.91 & 2.12 & 1.73 & 1.70 & 1.84 & 0.063 & $1.86^{\mathrm{b}} \pm 0.028$ \\
\hline & 4 & 1.85 & 2.05 & 1.72 & 1.83 & 1.87 & 0.063 & $1.86^{\mathrm{b}} \pm 0.028$ \\
\hline & 6 & 1.85 & 2.11 & 1.82 & 1.72 & 2.43 & 0.063 & $1.98^{\mathrm{a}} \pm 0.028$ \\
\hline Overall mean & & $1.89^{\mathrm{b}}$ & $2.06^{\mathrm{a}}$ & $1.81^{\mathrm{bc}}$ & $1.75^{\mathrm{c}}$ & $2.04^{\mathrm{a}}$ & 0.0317 & \\
\hline
\end{tabular}


values more than control and untreated group. The highest value was for T3 followed by T4 then T5, while the lowest value was for $\mathrm{T} 2$ followed by $\mathrm{T} 1$. The overall means of ruminal $\mathrm{pH}$ at the different sampling times showed a significant decrease $(\mathrm{P} \leq 0.01)$ post feeding to reach the lowest value at $4 \mathrm{hrs}$ post feeding then increased with progressed time of feeding at $6 \mathrm{hrs}$ post-feeding. This trend of ruminal $\mathrm{pH}$ may be related to ruminal fermentation process by rumen microorganisms. Total ruminal VFA's concentration ( $\mathrm{ml}$ equivalent/100 $\mathrm{ml} \mathrm{R.L}$ ) showed that biological treatments increased ruminal TVFA's concentration more than $\mathrm{T} 2$ and $\mathrm{T} 1$, the difference among biological treatments was not significant. It is clear that TVFA's concentration was in the contrary of $\mathrm{pH}$ values, whereas TVFA's concentration increased post feeding to reach the highest value at $4 \mathrm{hrs}$ post feeding then decreased with progressed time of feeding, this trend of TVFA's concentration might be related to the fermentation of unstructured carbohydrates of the ration as reported by Aziz (2004). Fouad (1991) concluded that the rumen pH in general decreased with increasing the TVFA's concentration in lambs rumen.

As for molar proportions of ruminal individual volatile fatty acids (\%), biological treatments significantly increased $(\mathrm{P} \leq 0.01)$ molar percentage of acetic, propionic and butyric more than control and untreated groups, T3 was significantly $(\mathrm{P} \leq 0.01)$ higher than all treatments followed by T4 then T5. The overall means of molar proportions of acetic, propionic and butyric at the different sampling times were the same trend of TVFA's. As for the acetic to propionic ratio, the values showed significant decrease $(\mathrm{P} \leq 0.01)$ in $\mathrm{T} 4$ more than other groups. The present data indicated that biological treatments for SBP and $\mathrm{OC}$ increased propionate production and decreased A/P ratio which also means an increase in propionate production, this increase is favorable as that propionate acts a very important role as a major precursor of hepatic gluconeogensis also propionate is a major precursor of meet which in turn help in during growth period or pregnancy period.

Total nitrogen, true protein nitrogen, non-protein nitrogen, ammonia nitrogen and microbial protein concentrations:

As given in Table (9) analysis of variance revealed a significant difference $(\mathrm{P} \leq 0.01)$ among the treated

Table (9): Effect of experimental treatments on total nitrogen, true protein nitrogen, non-protein nitrogen, ammonia nitrogen and microbial protein concentrations.

\begin{tabular}{|c|c|c|c|c|c|c|c|c|}
\hline \multirow[b]{2}{*}{ Item } & \multirow[b]{2}{*}{ Time } & \multicolumn{6}{|c|}{ Treatment } & \multirow[t]{2}{*}{ Overall mean } \\
\hline & & $\mathrm{T} 1$ & $\mathrm{~T} 2$ & T3 & $\mathrm{T} 4$ & T5 & $\pm \mathrm{SE}$ & \\
\hline nitrogen & 0 & 96.60 & 90.78 & 110.20 & 110.30 & 109.84 & 1.161 & $103.54^{\mathrm{d}} \pm 0.519$ \\
\hline \multirow[t]{3}{*}{ (mg/100 ml R.L) } & 2 & 108.57 & 105.16 & 119.45 & 120.55 & 118.51 & 1.161 & $114.45^{\mathrm{c}} \pm 0.519$ \\
\hline & 4 & 118.32 & 114.22 & 129.25 & 131.55 & 128.44 & 1.161 & $124.36^{\mathrm{a}} \pm 0.519$ \\
\hline & 6 & 109.57 & 106.22 & 121.45 & 122.55 & 123.51 & 1.161 & $116.66^{\mathrm{b}} \pm 0.519$ \\
\hline \multicolumn{2}{|l|}{ Overall mean } & $108.26^{b}$ & $104.10^{c}$ & $120.09^{\mathrm{a}}$ & $121.23^{\mathrm{a}}$ & $120.07^{\mathrm{a}}$ & 0.580 & \\
\hline protein & 0 & 39.19 & 33.63 & 38.70 & 40.64 & 47.14 & 1.550 & $39.86^{\mathrm{b}} \pm 0.693$ \\
\hline nitrogen $(\mathrm{mg} /$ & 2 & 40.54 & 38.21 & 39.55 & 37.76 & 41.55 & 1.550 & $39.52^{b} \pm 0.693$ \\
\hline \multirow[t]{2}{*}{100 ml R.L) } & 4 & 44.72 & 41.77 & 42.35 & 42.16 & 46.28 & 1.550 & $43.45^{\mathrm{a}} \pm 0.693$ \\
\hline & 6 & 39.54 & 38.77 & 39.55 & 37.73 & 44.45 & 1.550 & $40.01^{\mathrm{b}} \pm 0.693$ \\
\hline Overall mean & & $41.00^{\mathrm{b}}$ & $38.09^{c}$ & $40.03^{\mathrm{bc}}$ & $39.57^{\mathrm{bc}}$ & $44.85^{\mathrm{a}}$ & 0.775 & \\
\hline $\mathrm{NPN}(\mathrm{mg} / 100 \mathrm{ml}$ & 0 & 57.40 & 57.15 & 71.50 & 69.65 & 62.70 & 0.830 & $63.68^{c} \pm 0.371$ \\
\hline \multirow{3}{*}{ R.L) } & 2 & 68.02 & 66.95 & 79.90 & 82.79 & 76.96 & 0.830 & $74.92^{\mathrm{d}} \pm 0.371$ \\
\hline & 4 & 73.60 & 72.45 & 86.90 & 89.39 & 82.16 & 0.830 & $80.90^{\mathrm{a}} \pm 0.371$ \\
\hline & 6 & 70.02 & 67.45 & 81.90 & 84.81 & 79.06 & 0.830 & $76.65^{b} \pm 0.371$ \\
\hline Overall mean & & $67.26^{\mathrm{d}}$ & $66.00^{\mathrm{e}}$ & $80.05^{\mathrm{b}}$ & $81.66^{\mathrm{a}}$ & $75.22^{\mathrm{c}}$ & 0.415 & \\
\hline Ammonia & 0 & 27.52 & 27.52 & 31.17 & 34.36 & 31.27 & 0.336 & $30.36^{\mathrm{d}} \pm 0.150$ \\
\hline nitrogen & 2 & 29.00 & 28.25 & 36.70 & 38.05 & 32.39 & 0.336 & $32.88^{c} \pm 0.150$ \\
\hline \multirow[t]{2}{*}{100 ml R.L) } & 4 & 33.13 & 31.90 & 41.07 & 41.17 & 35.36 & 0.336 & $36.53^{\mathrm{a}} \pm 0.150$ \\
\hline & 6 & 29.92 & 28.83 & 38.79 & 39.65 & 34.09 & 0.336 & $34.26^{\mathrm{b}} \pm 0.150$ \\
\hline Overall mean & & $29.89^{\mathrm{d}}$ & $29.12^{\mathrm{e}}$ & $36.93^{\mathrm{b}}$ & $38.30^{\mathrm{a}}$ & $33.28^{c}$ & 0.168 & \\
\hline Microbial protein & 0 & 63.16 & 62.80 & 66.53 & 67.46 & 66.30 & 0.244 & $65.25^{\mathrm{d}} \pm 0.109$ \\
\hline \multirow[t]{3}{*}{ (mg/100mlRL) } & 2 & 102.64 & 102.48 & 109.65 & 109.55 & 107.22 & 0.244 & $106.31^{\mathrm{c}} \pm 0.109$ \\
\hline & 4 & 106.68 & 106.68 & 113.65 & 113.71 & 110.98 & 0.244 & $110.34^{\mathrm{a}} \pm 0.109$ \\
\hline & 6 & 104.74 & 103.61 & 112.82 & 112.72 & 109.12 & 0.244 & $108.60^{\mathrm{b}} \pm 0.109$ \\
\hline Overall mean & & $94.30^{\mathrm{c}}$ & $93.89^{d}$ & $100.66^{\mathrm{a}}$ & $100.86^{\mathrm{a}}$ & $98.40^{\mathrm{b}}$ & 0.122 & \\
\hline
\end{tabular}

Means with different letters with each row are significantly different $(P \leq 0.01)$. 
diets on ruminal fermentations. $\mathrm{T} 4$ had highest $(\mathrm{P} \leq 0.01)$ values of $\mathrm{TN}, \mathrm{NPN}, \mathrm{NH}_{3}$ and $\mathrm{MP}$, while $\mathrm{T} 5$ had highest $(\mathrm{P} \leq 0.01)$ value of $\mathrm{TP}$. It seems that $\mathrm{T} 4$ was more efficient in rumen fermentations followed $\mathrm{T} 3$ then T5, while T2 had the lowest values, T1 was moderated values. The overall means at different sampling times showed significant decrease $(\mathrm{P} \leq 0.01)$ for all rumen parameters at $2 \mathrm{hrs}$ post- feeding then showed a significant increase $(\mathrm{P} \leq 0.01)$ to reach the maximum value at 4 hrs post-feeding then showed decrease with progressed time of feeding at 6 hrs.

The present results of rumen parameters are consistent with those of several studies. Aziz (2004 and 2009) found that biological treatments for by-products improved ruminal pH, TVFA's, TN, TP, NPN and $\mathrm{NH}_{3}-\mathrm{N}$, also ruminal parameters were at minimum level before feeding then showed gradual increased to maximum level at 3 or $4 \mathrm{hrs}$ post feeding then tended to decrease by progressed time of feeding. Also, Kholif et al. (2005) showed that values of ruminal TVFA's increased significantly $(\mathrm{P}<0.05)$ with dietary treatment of $T$. viride followed by S. cerevisiae compared with the non-treated control. Aziz (2014 and 2015 ) found that rumen parameters and microbial protein production of sheep and goats were improved with ration contains SBP treated with T. viride and S. cerevisiae. Abdou (2017) found that biological treatments of $\mathrm{OC}$ improved ruminal $\mathrm{pH}$ and VFA's and $\mathrm{NH}_{3}$ concentrations of sheep.

\section{Ruminal ciliate protozoa:}

Data of Table (10) represented the identification of ruminal ciliate protozoa species and their density in the rumen liquor. Seven genera with 13 species and 7 subspecies of ruminal protozoa were identified in ruminal fluid of sheep in this study. These generas (genus) are Entodinum spp. [E. simplex, E. caudatum, E.bursa, E. minimum and E. triacum], Dasytrachia rummantium, Isotrachia spp. [I.intestinalis and I. prostoma], Ophryoscolox spp. [O. caudatus and O. purkynjei], Epidinium ecaudatum, Diplodinum anisacanthum and Polyolastron multivesiculatum. The values clearly showed that biological treatments significantly increased $(\mathrm{P} \leq 0.01)$ total and differential numbers of ruminal ciliate protozoa $\left(\times 10^{4} \mathrm{cell} / \mathrm{ml}\right.$ rumen liquor) more than $\mathrm{T} 1$ and $\mathrm{T} 2$. The highest $(\mathrm{P} \leq 0.01)$ values were for $\mathrm{T} 4$ followed by $\mathrm{T} 3$ then $\mathrm{T} 5 . \mathrm{T} 2$ takes the lowest $(\mathrm{P} \leq 0.01)$ values at all followed by $\mathrm{T} 1$. It seems that the highest presence among all species was for Entodinum spps followed by Dasytrachia and Polyolastron spps. protozoa counts significantly decreased $(\mathrm{P} \leq 0.01)$ at $2 \mathrm{hrs}$ post feeding then reached the maximum value at $4 \mathrm{hrs}$ post feeding then decreased with progressed time of feeding.

The present results are in agreement with Ivan et al. (2000) who found that Entodinum spp. was the most detrimental of ciliate protozoa species. Jouany et al. (1998) found that addition of live yeast culture to ruminant diet increased protozoa count.

Aziz (2004 and 2009) found that biological treatments for poor quality roughage increased total and differential numbers of ruminal protozoa. Also, Aziz (2014 and 2015) indicated an increase in ruminal ciliate protozoa for sheep and goats fed biologically treated SBP.

\section{Total bacteria and cellulolytic bacteria numbers:}

Data of Table (11) showed total bacteria $\left(\times 10^{8}\right.$ cell $/ \mathrm{ml}$ rumen liquor) and cellulolytic bacteria $\left(\mathrm{x} 10^{6}\right.$ cell $/ \mathrm{ml}$ rumen liquor) numbers, biological treatments increased $(\mathrm{P} \leq 0.01)$ their numbers more than $\mathrm{T} 1$ and T2. It seems that treatment with $C$. cellulasea (T5) came in the first class for the numbers of bacteria and cellulolytic bacteria followed by T3, while T4 came in the third class. The lowest numbers were for T2 followed by T1. The overall means of total and cellulolytic bacteria at different sampling times showed the same trend of protozoa count. Similar results were obtained by Dawson and Tricarico (2002) and Marghany et al. (2005) who reported that addition of live yeast culture to ruminant diet has improved fiber digestibility and stimulated cellulolytic bacteria. Also, Aziz (2014 and 2015) found an increase in total and cellulolytic bacteria numbers in rumen of goats and sheep fed biologically treated SBP.

\section{Blood parameters:}

Blood parameters as affected by treated diets are given in Table (12), biological treatments significantly increased $(\mathrm{P} \leq 0.01)$ serum total protein, albumin and globulin values $(\mathrm{g} / \mathrm{dl})$ more than control and untreated groups, the difference among the three biological treatments was not significant $(\mathrm{P} \leq 0.01)$. Biological treatments especially $\mathrm{T} 5$ decreased $(\mathrm{P} \leq 0.01)$ serum urea values $\mathrm{mg} / \mathrm{dl}$ more other treatments, the difference among biological treatments was not significant $(\mathrm{P} \leq 0.01)$. The decrease in serum urea can be attributed to the increase of $\mathrm{NH}_{3}-\mathrm{N}$ utilization by rumen microbes (Chaucheyars- Durand and Fonty, 2001), also, it is a real useful indicator for CP status and N metabolism (Valkeners et al., 2008). 
Table (10): Effect of experimental treatments on ruminal ciliate protozoa.

\begin{tabular}{|c|c|c|c|c|c|c|c|c|}
\hline \multirow[b]{2}{*}{ Item } & \multirow[b]{2}{*}{ Time } & \multicolumn{6}{|c|}{ Treatment } & \multirow[t]{2}{*}{ Overall mean } \\
\hline & & $\mathrm{T} 1$ & $\mathrm{~T} 2$ & $\mathrm{~T} 3$ & $\mathrm{~T} 4$ & $\mathrm{~T} 5$ & $\pm \mathrm{SE}$ & \\
\hline Total protozoa & 0 & 6.91 & 6.81 & 7.21 & 7.42 & 7.20 & 0.087 & $7.11^{c} \pm 0.039$ \\
\hline count $\times 10^{4}$ cell & 2 & 6.07 & 5.80 & 6.12 & 6.17 & 6.14 & 0.087 & $6.06^{\mathrm{d}} \pm 0.039$ \\
\hline$/ \mathrm{ml}$ rumen & 4 & 7.70 & 7.51 & 8.53 & 9.57 & 8.23 & 0.087 & $8.31^{\mathrm{a}} \pm 0.039$ \\
\hline liquor & 6 & 7.00 & 6.81 & 7.82 & 8.87 & 7.52 & 0.087 & $7.60^{\mathrm{b}} \pm 0.039$ \\
\hline Overall mean & & $6.92^{\mathrm{d}}$ & $6.73^{e}$ & $7.42^{\mathrm{b}}$ & $8.01^{\mathrm{a}}$ & $7.27^{\mathrm{c}}$ & 0.043 & \\
\hline Entodinum & 0 & 5.42 & 5.31 & 5.71 & 5.84 & 5.68 & 0.076 & $5.59^{c} \pm 0.034$ \\
\hline \multirow[t]{3}{*}{ spp. } & 2 & 4.96 & 4.73 & 5.01 & 5.03 & 5.01 & 0.076 & $4.95^{\mathrm{d}} \pm 0.034$ \\
\hline & 4 & 5.98 & 5.79 & 6.70 & 7.63 & 6.41 & 0.076 & $6.50^{\mathrm{a}} \pm 0.034$ \\
\hline & 6 & 5.48 & 5.29 & 6.20 & 7.13 & 5.91 & 0.076 & $6.00^{\mathrm{b}} \pm 0.034$ \\
\hline Overall mean & & $5.46^{\mathrm{d}}$ & $5.28^{\mathrm{e}}$ & $5.90^{\mathrm{b}}$ & $6.41^{\mathrm{a}}$ & $5.75^{c}$ & 0.038 & \\
\hline \multirow[t]{4}{*}{ Isotrachia spp. } & 0 & 0.217 & 0.216 & 0.207 & 0.220 & 0.211 & 0.005 & $0.214^{\mathrm{c}} \pm 0.002$ \\
\hline & 2 & 0.152 & 0.152 & 0.142 & 0.151 & 0.145 & 0.005 & $0.148^{\mathrm{d}} \pm 0.002$ \\
\hline & 4 & 0.261 & 0.260 & 0.279 & 0.278 & 0.272 & 0.005 & $0.270^{\mathrm{a}} \pm 0.002$ \\
\hline & 6 & 0.231 & 0.230 & 0.249 & 0.248 & 0.242 & 0.005 & $0.240^{\mathrm{b}} \pm 0.002$ \\
\hline Overall mean & & $0.215^{\mathrm{b}}$ & $0.214^{\mathrm{b}}$ & $0.219^{\mathrm{ab}}$ & $0.224^{\mathrm{a}}$ & $0.217^{\mathrm{ab}}$ & 0.002 & \\
\hline Dasytrachia & 0 & 0.394 & 0.414 & 0.434 & 0.442 & 0.432 & 0.007 & $0.423^{\mathrm{c}} \pm 0.003$ \\
\hline \multirow[t]{3}{*}{ spp. } & 2 & 0.364 & 0.343 & 0.361 & 0.362 & 0.360 & 0.007 & $0.358^{\mathrm{d}} \pm 0.003$ \\
\hline & 4 & 0.487 & 0.487 & 0.490 & 0.567 & 0.488 & 0.007 & $0.504^{\mathrm{a}} \pm 0.003$ \\
\hline & 6 & 0.457 & 0.457 & 0.460 & 0.537 & 0.458 & 0.007 & $0.474^{\mathrm{b}} \pm 0.003$ \\
\hline Overall mean & & $0.425^{\mathrm{b}}$ & $0.425^{\mathrm{b}}$ & $0.436^{\mathrm{b}}$ & $0.477^{\mathrm{a}}$ & $0.434^{\mathrm{b}}$ & 0.003 & \\
\hline \multirow[t]{4}{*}{ Epidinium spp. } & 0 & 0.183 & 0.178 & 0.185 & 0.190 & 0.182 & 0.003 & $0.184^{\mathrm{b}} \pm 0.001$ \\
\hline & 2 & 0.117 & 0.115 & 0.116 & 0.122 & 0.120 & 0.003 & $0.118^{c} \pm 0.001$ \\
\hline & 4 & 0.199 & 0.197 & 0.229 & 0.232 & 0.223 & 0.003 & $0.216^{a} \pm 0.001$ \\
\hline & 6 & 0.164 & 0.162 & 0.194 & 0.197 & 0.188 & 0.003 & $0.181^{\mathrm{b}} \pm 0.001$ \\
\hline Overall mean & & $0.166^{\mathrm{c}}$ & $0.163^{c}$ & $0.181^{\mathrm{ab}}$ & $0.185^{\mathrm{a}}$ & $0.178^{b}$ & 0.001 & \\
\hline Polyolastron & 0 & 0.361 & 0.363 & 0.346 & 0.376 & 0.331 & 0.005 & $0.355^{\mathrm{b}} \pm 0.002$ \\
\hline \multirow[t]{3}{*}{ spp. } & 2 & 0.287 & 0.278 & 0.301 & 0.301 & 0.290 & 0.005 & $0.291^{\mathrm{c}} \pm 0.002$ \\
\hline & 4 & 0.353 & 0.365 & 0.401 & 0.428 & 0.410 & 0.005 & $0.392^{\mathrm{a}} \pm 0.002$ \\
\hline & 6 & 0.317 & 0.329 & 0.365 & 0.392 & 0.374 & 0.005 & $0.356^{\mathrm{b}} \pm 0.002$ \\
\hline Overall mean & & $0.329^{c}$ & $0.334^{c}$ & $0.353^{\mathrm{b}}$ & $0.374^{\mathrm{a}}$ & $0.351^{\mathrm{b}}$ & 0.002 & \\
\hline Ophryoscolox & 0 & 0.183 & 0.192 & 0.190 & 0.194 & 0.187 & 0.001 & $0.189^{c} \pm 0.001$ \\
\hline \multirow[t]{3}{*}{ spp. } & 2 & 0.116 & 0.114 & 0.120 & 0.122 & 0.116 & 0.001 & $0.118^{\mathrm{d}} \pm 0.001$ \\
\hline & 4 & 0.226 & 0.222 & 0.232 & 0.234 & 0.229 & 0.001 & $0.229^{\mathrm{a}} \pm 0.001$ \\
\hline & 6 & 0.190 & 0.186 & 0.196 & 0.198 & 0.193 & 0.001 & $0.193^{\mathrm{b}} \pm 0.001$ \\
\hline Overall mean & & $0.179^{\mathrm{bc}}$ & $0.178^{c}$ & $0.185^{\mathrm{a}}$ & $0.187^{\mathrm{a}}$ & $0.181^{b}$ & 0.001 & \\
\hline Diplodinum & 0 & 0.147 & 0.142 & 0.153 & 0.158 & 0.152 & 0.001 & $0.150^{\mathrm{c}} \pm 0.001$ \\
\hline \multirow[t]{3}{*}{ spp. } & 2 & 0.076 & 0.073 & 0.081 & 0.083 & 0.080 & 0.001 & $0.078^{\mathrm{d}} \pm 0.001$ \\
\hline & 4 & 0.194 & 0.189 & 0.199 & 0.200 & 0.196 & 0.001 & $0.196^{\mathrm{a}} \pm 0.001$ \\
\hline & 6 & 0.158 & 0.153 & 0.163 & 0.164 & 0.160 & 0.001 & $0.160^{\mathrm{b}} \pm 0.001$ \\
\hline Overall mean & & $0.144^{\mathrm{d}}$ & $0.139^{c}$ & $0.149^{\mathrm{a}}$ & $0.151^{\mathrm{a}}$ & $0.147^{\mathrm{b}}$ & 0.001 & \\
\hline
\end{tabular}

Means with different letters with each row are significantly different $(P \leq 0.01)$.

Table (11): Effect of experimental treatments on total bacteria and cellulolytic bacteria numbers.

\begin{tabular}{|c|c|c|c|c|c|c|c|c|}
\hline \multirow[b]{2}{*}{ Items } & \multirow[b]{2}{*}{ Time } & \multicolumn{6}{|c|}{ Treatments } & \multirow[t]{2}{*}{ Overall mean } \\
\hline & & $\mathrm{T} 1$ & $\mathrm{~T} 2$ & T3 & $\mathrm{T} 4$ & T5 & $\pm \mathrm{SE}$ & \\
\hline Total bacterial & 0 & 3.41 & 3.84 & 4.27 & 4.18 & 4.43 & 0.026 & $4.03^{c} \pm 0.011$ \\
\hline numbers $\times 10^{8}$ cell & 2 & 3.85 & 4.11 & 4.70 & 4.70 & 4.76 & 0.026 & $4.42^{\mathrm{b}} \pm 0.011$ \\
\hline \multirow[t]{2}{*}{$/ \mathrm{ml}$ rumen } & 4 & 4.32 & 4.58 & 4.97 & 4.84 & 5.15 & 0.026 & $4.77^{\mathrm{a}} \pm 0.011$ \\
\hline & 6 & 4.14 & 4.29 & 4.73 & 4.48 & 4.48 & 0.026 & $4.42^{\mathrm{b}} \pm 0.011$ \\
\hline overall mean & & $3.93^{c}$ & $4.21^{\mathrm{d}}$ & $4.67^{\mathrm{a}}$ & $4.55^{\mathrm{b}}$ & $4.71^{\mathrm{a}}$ & 0.013 & \\
\hline Cellulolytic bacteria & 0 & 3.16 & 3.01 & 4.19 & 4.12 & 4.29 & 0.119 & $3.75^{\mathrm{c}} \pm 0.053$ \\
\hline numbers $\times 10^{6}$ cell & 2 & 3.51 & 3.33 & 4.41 & 3.94 & 4.66 & 0.119 & $3.97^{\mathrm{b}} \pm 0.053$ \\
\hline \multirow[t]{2}{*}{$/ \mathrm{ml}$ rumen } & 4 & 3.78 & 3.60 & 4.88 & 4.75 & 4.95 & 0.119 & $4.39^{\mathrm{a}} \pm 0.053$ \\
\hline & 6 & 3.48 & 3.33 & 4.40 & 4.37 & 4.40 & 0.119 & $3.99^{b} \pm 0.053$ \\
\hline overall mean & & $3.48^{c}$ & $3.31^{\mathrm{d}}$ & $4.47^{\mathrm{a}}$ & $4.29^{\mathrm{b}}$ & $4.58^{\mathrm{a}}$ & 0.059 & \\
\hline
\end{tabular}

Means with different letters with each row are significantly different $(P \leq 0.01)$. 
Table (12): Effect of experimental treatments on some blood parameters.

\begin{tabular}{|c|c|c|c|c|c|c|c|c|}
\hline \multirow[b]{2}{*}{ Item } & \multirow[b]{2}{*}{ Time } & \multicolumn{6}{|c|}{ Treatment } & \multirow[t]{2}{*}{ Overall mean } \\
\hline & & $\mathrm{T} 1$ & $\mathrm{~T} 2$ & T3 & $\mathrm{T} 4$ & T5 & $\pm \mathrm{SE}$ & \\
\hline \multirow[t]{2}{*}{ Total proteins $\mathrm{g} / \mathrm{dl}$} & 0 & 7.35 & 7.12 & 7.87 & 7.85 & 7.86 & 0.090 & $7.61^{\mathrm{b}} \pm 0.040$ \\
\hline & 4 & 8.15 & 7.53 & 8.48 & 8.46 & 8.26 & 0.090 & $8.17^{\mathrm{a}} \pm 0.040$ \\
\hline Overall mean & & $7.75^{\mathrm{b}}$ & $7.32^{\mathrm{c}}$ & $8.17^{\mathrm{a}}$ & $8.15^{\mathrm{a}}$ & $8.06^{\mathrm{a}}$ & 0.063 & \\
\hline \multirow[t]{2}{*}{ Albumin g/dl } & 0 & 3.99 & 3.48 & 4.18 & 3.82 & 3.99 & 0.061 & $3.89^{\mathrm{b}} \pm 0.027$ \\
\hline & 4 & 4.28 & 4.11 & 4.49 & 4.73 & 4.51 & 0.061 & $4.42^{\mathrm{a}} \pm 0.027$ \\
\hline Overall mean & & $4.14^{\mathrm{b}}$ & $3.80^{c}$ & $4.33^{\mathrm{a}}$ & $4.27^{\mathrm{ab}}$ & $4.25^{\mathrm{ab}}$ & 0.043 & \\
\hline \multirow[t]{2}{*}{ Globulin g/dl } & 0 & 3.35 & 3.63 & 3.68 & 4.03 & 3.86 & 0.097 & $3.71 \pm 0.043$ \\
\hline & 4 & 3.86 & 3.41 & 3.99 & 3.72 & 3.75 & 0.097 & $3.75 \pm 0.043$ \\
\hline Overall mean & & $3.60^{\mathrm{bc}}$ & $3.52^{\mathrm{c}}$ & $3.84^{\mathrm{a}}$ & $3.87^{\mathrm{a}}$ & $3.81^{\mathrm{ab}}$ & 0.068 & \\
\hline \multirow[t]{2}{*}{$\mathrm{A} / \mathrm{G}$ ratio } & 0 & 1.19 & 0.98 & 1.13 & 0.95 & 1.03 & 0.039 & $1.05^{\mathrm{b}} \pm 0.017$ \\
\hline & 4 & 1.10 & 1.21 & 1.12 & 1.28 & 1.20 & 0.039 & $1.18^{\mathrm{a}} \pm 0.017$ \\
\hline Overall mean & & 1.14 & 1.09 & 1.13 & 1.11 & 1.12 & 0.027 & \\
\hline \multirow[t]{2}{*}{ Urea mg/dl } & 0 & 29.95 & 32.16 & 23.18 & 23.02 & 23.36 & 0.445 & $26.33^{\mathrm{b}} \pm 0.199$ \\
\hline & 4 & 39.18 & 37.67 & 30.41 & 31.26 & 31.43 & 0.445 & $33.99^{\mathrm{a}} \pm 0.199$ \\
\hline Overall mean & & $34.56^{\mathrm{a}}$ & $34.92^{\mathrm{a}}$ & $26.79^{b}$ & $27.14^{\mathrm{b}}$ & $27.39^{\mathrm{b}}$ & 0.314 & \\
\hline \multirow[t]{2}{*}{ GOT U/L } & 0 & 23.27 & 23.41 & 22.28 & 22.40 & 21.15 & 0.271 & $22.50^{\mathrm{b}} \pm 0.121$ \\
\hline & 4 & 26.13 & 26.14 & 25.33 & 25.17 & 26.30 & 0.271 & $25.81^{\mathrm{a}} \pm 0.121$ \\
\hline Overall mean & & $24.70^{\mathrm{a}}$ & $24.78^{\mathrm{a}}$ & $23.81^{\mathrm{b}}$ & $23.78^{\mathrm{b}}$ & $23.72^{\mathrm{b}}$ & 0.191 & \\
\hline \multirow[t]{2}{*}{ GPT U/L } & 0 & 15.26 & 15.18 & 15.20 & 12.55 & 15.12 & 0.828 & $14.66^{\mathrm{b}} \pm 0.370$ \\
\hline & 4 & 16.86 & 17.22 & 16.75 & 16.87 & 17.15 & 0.828 & $16.97^{\mathrm{a}} \pm 0.370$ \\
\hline Overall mean & & 16.06 & 16.20 & 15.97 & 14.71 & 16.13 & 0.585 & \\
\hline
\end{tabular}

Means with different letters with each row are significantly different $(P \leq 0.01)$.

Serum GOT activity values (U/L) were similar to serum urea values trend. While GPT activity (U/L) was not significantly differed $(\mathrm{P} \leq 0.01)$ among treatments, the lowest value was recorded for T4 followed by T5. All blood parameters showed a significant increase $(\mathrm{P} \leq 0.01)$ after 4 hrs post feeding compared to pre-feeding values. It seems that biological treatments did not cause any abnormal conditions in liver and kidney functions.

Similar results were obtained with biological treatments by Kholif et al. (2005) and Aziz (2009) who reported an increase in total protein, albumin and globulin concentrations, and a decrease in urea, GOT and GPT concentrations in blood serum. Also, Aziz (2014 and 2015) indicated that blood parameters improved for sheep and goats fed biologically treated SBP.

\section{CONCLUSION}

It can be concluded that, inclusion of dried sugar beet pulp and dried olive cake untreated or treated with biological treatments to replace a part of $70 \%$ of common concentrate feed mixture had remarkable improved influence on chemical composition, nutrients digestibility coefficients, nitrogen balance, rumen parameters, microbial protein and ruminal protozoa and bacteria numbers, all these improvements will enhance animal performance. Also, inclusion of SBP and OC decreased feed costs more than control group.

\section{REFERENCES}

Abdou, R. Ahlam (2017). Utilization of allzyme SSF to improve the nutritive value of olive cake in sheep. Egyptian J. Nutrition and Feeds. 20 (30):379-387.

Abedo, A.A., M.A. El-Ashry, A.Y. El-Badawi, F.I.S. Helal and M. Fadel (2005). Effect of feeding biologically treated sugar beet pulp on growth performance of sheep. Egyptian J. Nutrition and Feeds. 8: 579-590. 
Aboul-Fotouh, G.E., M. Kamel, H. Rady and H. Mahfouz (2013). Effect of olive cake level in sheep ration without or with urea or yeast on digestibility coefficients and nutritive value. Egyptian $\mathrm{J}$. Nutrition and Feeds. 18(2):225-233.

Ahmad, V.U., S. Perveen and S. Bano (1990). Saponins from the leaves of Guaiacum officinale. Phytochemistry, 29:3287-3290.

Allam, M. Sabbah; T.M. Al-Bedawi; Hanaa H. El-Amary and Shereen H. Mohamed (2006). Improving sugar beer pulp through biological treatment and its use in sheep ration. Egyptian J. Nutrition and Feeds.9(2): 235-247.

AOAC (1995). Association of Official Analytical Chemists. Official methods of analysis. $15^{\text {th }}$ ed. Arlongton, Virginia, USA.

Arambewela, L. and T. Ranatunge (1991). Indole alkaloids from Tabernaemontana divaricate. Phytochemistry, 30:1740-1741.

Armstrong, W.D. and C.W. Carr (1964). Physiological Chemistry, 3ed Ed. Laboratory Directions Bures Publishing Co. Minneapolis, Minnesota, USA.

Aziz ,Hend, A. (2004). Studies on effect of some non-hormonal growth promoters on growth rate and some rumen parameters in small ruminants under desert condition. M. Sc. Thesis, Fac. of Agric., Ain Shams Univ.

Aziz, Hend, A. (2009). Effect of feeding olive tree pruning by-products in Sinai on sheep performance. Ph. D. thesis, Fac. of Agric., Ain Shams Univ.

Aziz, Hend, A. (2014). Effect of biologically treated sugar beet pulp on chemical composition, nutrients disappearance, digestibility, rumen fermentations, rumen microbes and blood composition in adult sheep. J. Agric. Sci. Mansoura Univ., 5(12): 647-671.

Aziz, Hend, A. (2015). Effect of biologically treated sugar beet pulp on lactating goat performance. J. Agric. Sci. Mansoura Univ., 6 (6): 301-327.

Boham, B.A. and A.C. Kocipai (1994). Flavonoids and condensed tannins from the leaves of Hawaiian vaccinium vaticulatum and V. calycinium. Pacifici Sci., 48:458-463.

Bryant, M.P. (1972). Commentary on the Hugate technique for culture of anaerobic bacteria. Am. J. Clin. Nutr. 25:1324.

Chaucheyars- Durand, F. and G. Fonty (2001). Establishment of cellulolytic bacteria and development of fermentative activities in the rumen of gnotobiotically-reared lambs receiving the microbial additive Sacharomyces cerevisiae CNCM 1-1077. Reprod. Nutr. Dev. 41: 57-68.

Church, D.C. and W.G.Pond (1982). Basic animal nutrition and feeding, 2nd ed. Johnwiley and sons, New York, U.S.A.

Dawson, K. A. and J. Tricarico (2002). The evaluation of yeast cultures 20 years of research. Proceedings of Alltech's $16^{\text {Th }}$ Annual Symposium, Alltech Technical Publications, European, Middle Eastern and African Lecture Tour.

Dehority, B. A. (1993). Laboratory Manual for Classification and Morphology of Rumen Ciliate Protozoa. CRC. Press Inc., Florida.

Doumas, Wabson and H. Biggs. (1971). Albumin standards and measurement of serum with bromocresol green. Din. Cherm. Acta. 31: 87.

Duncan, D.B. (1955). Multiple range and multiple F-test. Biometrics. 11:1-42.

El-Ashry, M.A., A.M. Kholif, M. Fadel, H.A. El-Alamy, H.M. El-Sayed and S.M. Kholif (2003). Effect of biological treatments on chemical composition and in vitro and in vivo digestibilities of poorquality roughages. Egyptian J. Nutr. and Feeds, 6:113-126.

Fouad, R.T. (1991). Effect of some mechanical treatments and feed additives on the nutritional value of corn stalks. M.Sc. Thesis, Fac. of Aric., Al-Azhar Univ.

Gomaa, A.A.A.I., M.Y. Mohamed, Fatma E. Saba, E.M.M. Ibrahim, A.A. El-Giziry (2016). Growth performance of Ossimi lambs as affective microorganisms. 
Haaksma, J. (1982). Feeding value of pressed beet pulp compared to other fodders. Proc. Int. Inst. Sugar Beet Research, 45th Winter Congress, USA.

Israilides, C.J., D.Iconomou, K. Kandylis and P. Nikokyris (1994). Fermentability of sugar beet pulp and its acceptability in mice. Bioresour Technology 47, 97.

Ivan, M., L. Neill, R. Forster, R. Alimon, T.L.M. Rode, and T. Entz, (2000). Effects of Isotricha, Dasytricha, Entodinium and total Fauna on ruminal fermentation and duodenal flow in wethers fed different diets. J. Dairy Sci. 83: 776-787.

Jouany, J.P., F. Mathieu, J. Senaud, J. Bohatier and M. Mercier (1998). The effect of Sacharomyces cerevisiae and Asarglus orsa on the digestion of the cell wall fraction of a mixed diet in defaunated and refaunated sheep rumen. Reproduction Nutrition Development, 38:401-416.

Khampa, S., P. chaowwarat, R. Singhalert, R. Pilajun and M. Wanapat (2009). Supplementation of yeast fermented Cassava chip as a replacement concentrate on rumen fermentation efficiency and digestibility of nutrients in heifer. J.Anim. and Vet. Advances. 8(6):1091-1095.

Kholif, A.M., M.A. El-Ashry, H.A. El-Alamy, H.M. El-Sayed, M. Fadel, and S.M. Kholif (2005). Biological treatments of banana wastes for feeding lactating goats. Egyptian J. Nutrition and Feeds. (2): $149-162$.

Makkar, H.P.S. (2000). Quantification of Tannins in Tree Foliage. A Laboratory Manual for the FAO/IAEA Coordinated Research Project on the Use of Nuclear and Related Techniques to Develop Simple Tannin Assays for Predicting and Improving the Safety and Efficiency of Feeding Ruminants on Tanniniferous Tree Foliage. FAO/IAEA Working Document, IAEA, Austria, p.38.

Mann, S. O. (1968). An inmproved method for determining cellulolytic activity in anaerobic bacteria. J. Appl. Bacteriol. 31:241.

Mansfield, H.R., M.D. Stern and D.E. Otterby (1994). Effects of beet pulp and animal by-products on milk yield and in vitro fermentation by rumen microorganisms.J. Dairy Sci., 77:205.

Marghany, M., M.A. Sarhan, A. Abd El-Hey and A.A.H. El-Tahan (2005). Performance of lactating buffaloes fed rations supplemented with different levels of baker's yeast (Saccharomyces cerevisiae). Egyptian J. Nutrition and Feeds. (Special Issue), 8:21.

Martın Garcia, A.I., A. Moumen, D.R. Yanez Ruiz, E. Molina Alcaide (2003). Chemical composition and nutrients availability for goats and sheep of two-stage olive cake and olive leaves. Anim. Feed Sci. Technol. 107, 61- 74.

Nigam, P. (1994). Process selection for protein enrichment; fermentation of the sugar industry byproducts molasses and sugar beet pulp. Process Biochemistry. 29:337.

Norris, K.H. (1976). Predicting forage quality by infrared reflectance spectroscopy. J.Anim. Sci., 43:889.

Ogimoto, K. and S. Imai (1981). Atals of Rumen Microbial-Ogy. Japan Scientific Societies Press, ToKyo.

Patton, C. J. and S.R. Crouch (1977). Spectrophotomentic and kinetics investigation of the Berthelot reaction for the determination of ammonia. Anal. Chem., 49: 464-469.

Porter, L.J., L.N. Hrstich and B.G. Chan (1986). The conversion of procyanidins and prodelphinidins to cyaniding and delphinidins. Phytochemistry 1:223-230.

Salama, A.A. (2013). Increasing utilization of olive cake in local laying hen diets by clay supplementation. Egyptian J. Nutrition and Feeds. 16(2):327-344.

SAS (2004). SAS/STAT 9.1.3 User's Guide: Statistical Analysis Systems Institute Inc., Release 8.1, Cary, NC., USA.

Statistics of Ministry of Agriculture, Egypt (2011). Economic Affairs, Sector of Agricultural Statistics. 2011.

Teimouri Yansari, A., H. Sadeghi, Z. Ansari-Pirsarai and H. Mohammad-Zadeh (2007). Ruminal dry matter and nutrient degradability of different olive cake by-products after incubation in the rumen using nylon bag technique. Int. J. Agric. Biol., 9:439-442.

Valkeners, D., A. Thewis, M. Van Laere and Y. Beckers (2008). Effect of rumen degradable protein balance deficit on voluntary intake, microbial protein synthesis and nitrogen metabolism in growing double-muscled Belgian Blue bulls fed corn silage- based diet. J. Anim. Sci. 86:680-690. 
Van Soest, P. J. (1994). The Nutritional Ecology of the Ruminant, $2^{\text {nd }}$ edition. Cornell University Press. Ithaca, N Y., 476p.

Warner, A.C.J. (1964). Production of volatile fatty acids in the rumen methods of measurments. Nutr. Abst. \& Rev.34:339.

Wikison, J.H., D.N. Barn, D.W. Moss and P.G. Walker (1972). Standardization of clinical enzyme assays. A reference method for aspartate and alanine transaminases. J. Clin. Pathol., 25:940.

\section{القيمة الذذائية لتفل بنجر السكر وتفل الزيتون المعامل باستخدام المعاملة البيولوجية الفردية وتأثير ها على تغذية}

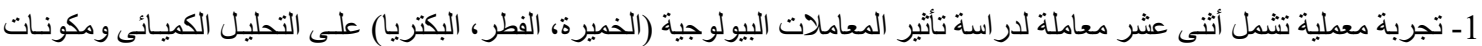

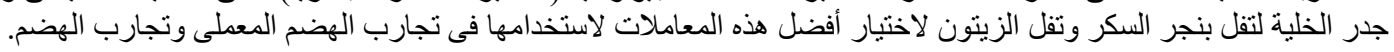

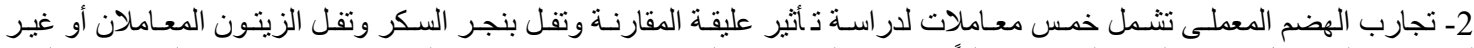

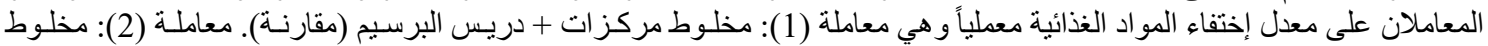

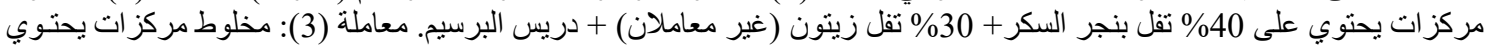

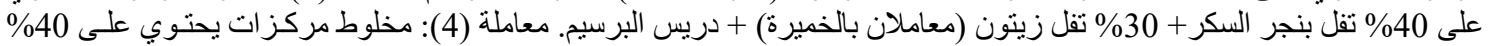

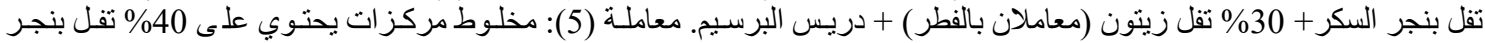
السكر + 30\% تفل زيتون (معاملان بالبكتريا) + دريس البرسيخ.

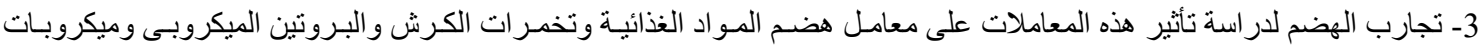
الكرش وبعض مكونات الدم فى الأغنام.

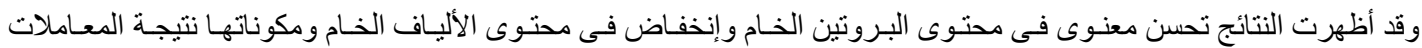

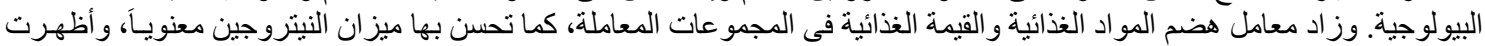

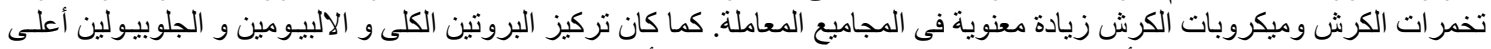

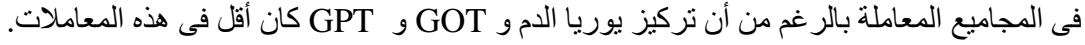

